\title{
The N-Word at Work: Contextualizing Language in the Workplace
}

\section{Leora F. Eisenstadt $\dagger$}

The N-Word at Work examines the misinterpretation of language in employment discrimination cases. There is a widening gap between the use and meaning of words in modern American culture and courts' treatment of those words. This is particularly true of derogatory slurs and phrases, but is equally true for discriminatory language in general. This Article argues for a context-driven theory of linguistic meaning that comports with the purposes of Title VII and other anti-discrimination statutes but also reinjects a sense of reality into the consideration of discriminatory language.

Both the legal literature and judicial system have largely ignored this problem of language in discrimination cases. Perhaps sensing an emerging problem in the lower courts, in its 2006 decision in Ash v. Tyson, the Supreme Court devoted a single, vague sentence to the meaning of language in discrimination cases. Nonetheless, the problem persists among appellate and district courts alike. In late 2010, for example, a federal district court in Philadelphia addressed the issue head-on in a case involving a white employee who was terminated for using "the $N$-word" and claimed in his reverse-race discrimination case that had he been African American and used the word, he would not have been disciplined. Like its predecessors, the court approached the problem in a formalistic way that resulted in a context-blind approach to language with unsatisfactory results.

$\dagger$ Abraham L. Freedman Fellow, Temple University Beasley School of Law; B.A., Yale University; J.D., New York University School of Law. Many thanks to my colleagues at Temple whose feedback contributed enormously to this article: Jeremi N. Duru, Richard Greenstein, Theresa Glennon, Gregory Mandel, and Brishen Rogers. I am grateful also for the thoughtful and deep feedback from Deborah Malamud and Sylvia Law at NYU. Thank you also to my former colleagues at Dechert LLP with whom 1 began to think about this problem: Jerome Hoffman, Thomas Johnson, III, Vernon Francis, and Jane Patullo. The article also benefitted from the careful and attentive reading of my research assistant, Erica Fruiterman. Finally, thank you to my husband, Mike Uram, whose patience and support was and is always indispensable. 
This Article calls attention to the issue by examining the uses and meanings of discriminatory language in modern culture and advocates a theory of meaning that relies on the context in which language is used; the identity of the user; and the social, historical, and cultural framework in which the language developed. The Article highlights the mistreatment of language by trial and appellate courts and tracks the troubling history of Ash, which was finally resolved in December 2011 after two trials, a trip to the Supreme Court, and four reviews by the Eleventh Circuit. Finally, the Article suggests solutions to this seemingly intractable problem, including the need for (1) robust guidance from the Supreme Court on the purposes of anti-discrimination laws and the non-literal applications of those laws that make flexible, context-driven considerations of discriminatory language both possible and preferable; and (2) extra-legal expert testimony akin to social framework evidence that could translate the cultural realities of language for courts.

INTRODUCTION 301

I. THE BURLINGTON CASE AND ITS CULTURAL COMPANIONS ................. 304

A. Similar Incidents Among Celebrities and Ordinary Citizens.. 306

B. Identity and Discriminatory Language in Popular Culture ..... 310

C. The Complexities of the N-Word and Other Slurs ................ 312

II. THE CONTEXT-DRIVEN MEANING OF LANGUAGE ............................ 314

A. Linguistic Power ................................................................. 314

B. Context as Driver of Meaning.......................................... 316

III. THE MistREATMENT OF LANGUAGE BY COURTS ........................... 320

A. The Ash v. Tyson Saga .................................................. 322

B. The Treatment of Discriminatory Language by Other District and Appellate Courts............................................. 328

C. Misinterpretation of Language as a Result of an Overly Narrow Approach to Discrimination Cases Generally ........... 336

D. Endorsing a Flexible Reading of Antidiscrimination

Statutes that Supports Their Essential Purpose

IV. POSSIBLE SOLUTIONS TO THE PROBLEM OF MISINTERPRETATION OF DISCRIMINATORY LANGUAGE

A. Incorporating Expert Evidence to Insure Consideration of Linguistic Realities

1. Burlington as a Case Study for the Potential Role of Expert Evidence

B. Potential Weaknesses and Questions Raised by this

Solution 348 


\section{INTRODUCTION}

On June 23, 2007, Thomas Burlington, a white news anchor at Philadelphia's local Fox Television Station, used the word "nigger" during a newsroom meeting. He subsequently apologized to offended colleagues, but made the questionable choice of repeating the word during many of these conversations. After the incident leaked to the press, numerous articles in both local newspapers and online news sources featured it. The station initially suspended Mr. Burlington and sent him to sensitivity training, but ultimately declined to permit him back on the air and renew his contract when it expired. In 2009, Mr. Burlington sued the station, claiming reverse race discrimination and contending that, had he been African American and used the word as he did, he would not have been disciplined in the same way. ${ }^{2}$

Why does this case sound somewhat absurd? Reverse race discrimination claims, although suspect in some circumstances, are by no means uncommon. But this particular reverse race claim contained a unique element-the notion that the right to use words is an inherently equal one regardless of time, relationship of the parties, and racial or other identity. While the argument has some appeal on its face $e^{3}$ the contention that we are all equally entitled to language rings untrue in our modern culture. This, I contend, is a function of the meaning of language. Words do not have static meaning, but rather undergo transformations that may be minor or dramatic depending on the context in which they are used; the identity of the speaker; and the social structure and culture in which the words are introduced. Words have immense power, both to induce action and to affect reality, but the magnitude of that power is intimately related to the context in which the speaker uses the words. Thus, the meaning and

1. Although I recognize the irony of a white woman using this term in a paper discussing the meaning of language and the impact of one's identity on that meaning, I have made the conscious choice to use it, sparingly and only when necessary, in order to have a full and intellectually honest discussion in the context of a scholarly article. My use of the term (or any number of other derogatory terms that appear in this paper) is not meant to offend in any way.

2. See Burlington v. News Corp., 759 F. Supp. 2d 580, 584-89, 592 (E.D. Pa. 2010). For purposes of full disclosure, I worked on this case as an associate at Dechert LLP in Philadelphia, representing the defendants. This article does not discuss anything about the case that does not appear in the public record.

3. Title VII, at least, embodies "formal equality," making this reverse race claim somewhat appealing. See Lisa Eichhorn, Hostile Environment Actions, Title VII, and the ADA: The Limits of the Copy-and-Paste Function, 77 WASH. L. REV. 575, 593 (2002) ("Title VII jurisprudence, including hostile environment doctrine, is likely to hew very closely to the formal equality model for the foreseeable future."). 
power of discriminatory language varies widely based on context, the relationship of the parties in question, and the historical realities that inform the meaning of the word used. The decision when to punish such speech or when such speech is evidence of unlawful bias necessarily depends on these factors. One central factor is the identity of the speaker-including his race, religion, gender, and sexual orientation.

Nonetheless, in Burlington v. News Corp., the court concluded that it could not dismiss the case on summary judgment because of the literal text of Title VII. It specifically opined that the term "nigger" is a word with varied meanings and that those meanings tend to be determined by the identity of the speaker. The court, however, felt that it could not "conclude that this is a justifiable reason for [an employer] to draw race-based distinctions between employees," and therefore refused to interpret Title VII "in accord with prevailing social norms."

The Burlington case is by no means the first employment discrimination case to rest on the use of racially-tinged language or even on the term nigger. As Randall Kennedy demonstrated in his widely discussed book, Nigger: The Strange Career of a Troublesome Word ${ }^{5}$ there is a long history of employment discrimination cases involving that term. In fact, Kennedy's book elucidates the prevalence of the slur in lawsuits of all kinds-most commonly in discrimination cases. ${ }^{6}$ Burlington differs from typical cases involving the slur in that it involves non-interlocutory discourse as the slur was spoken but not directed at a person or group of people. Nonetheless, what the case highlights is a problem that is increasingly common in cases involving discriminatory language (often in the employment context): courts' overly formalistic approach to language with the result that either (1) the contextual realities of usage and meaning are ignored to the detriment of a deserving plaintiff or a well-meaning employer or (2) courts actually consider the cultural and historical context of words but refuse to admit it, leading to disingenuous opinions that pollute the waters for future cases. Although Kennedy's book points out the varied meanings of the term depending upon speaker and audience, it does not consider the fact that courts have largely ignored the contextual implications for the meaning of the term and numerous other slurs. This Article breaks new ground by arguing that the realities of our culture demand a new approach to language in discrimination cases. Courts must acknowledge the context-driven realities of language, the historical meaning and import of words, and the fact that the identities of the speaker

4. Burlington, 759 F. Supp. $2 d$ at 597.

5. Randall Kennedy, Nigger: The Strange Career of a Troublesome Word (2002).

6. Id. at $46-47$. 
and listeners often influence meaning. Employers, by extension, should be permitted to consider the race, sex, and other identities of the speaker when determining how to handle workplace incidents involving questionable language, even though it may run afoul of a literal reading of Title VII and Section $1981 .^{7}$

This Article will consider the use of words in our culture and will discuss a theory of meaning that is based on the context-driven nature of language. It will then highlight some examples of the mistreatment or disingenuous treatment of language by trial and appellate courts. The Article will track the strange and troubling history of Ash v. Tyson, which involved the derogatory use of the term "boy," and which required two trials, numerous appellate opinions, and a trip to the Supreme Court, before final disposition by the Eleventh Circuit in December 2011. ${ }^{8}$ Finally, this Article will suggest a potential solution to the problem of acontextual treatment of language, namely the allowance of expert testimony from disciplines outside of the law that can inform courts about the way in which linguistic meaning is created in our culture and the contextually-based meanings of specific terms.

Part I will review the Burlington case in more detail and will consider the cultural reality in which it arose. Part II will consider the context-driven nature of language and the sources of meaning in our culture to demonstrate

7. Notwithstanding this point, I want to make clear that I am not making a judgment about what discipline is appropriate for someone who uses a racial-, ethnic-, sexual-, or sexual orientation-related slur, regardless of the identity of the speaker. Whether it is proper to fire someone for one such incident is not my concern, nor do I take any position on a particular workplace's choice to completely abolish a word from its premises regardless of the speaker's identity. Those are decisions that must be made on an individual basis and perhaps reviewed by a jury. My point here is to suggest that in deciding if and how to punish employees for their words, employers should consider the context in which the word was used, including the identity of the speaker, and that they should not be seen as violating Title VII by doing so.

In addition, the intersection between freedom of speech and discrimination is beyond the scope of this article. This is a confusing point for non-lawyers, and those out-group members who feel victimized by this issue often point to free speech as their protector in all situations. Nonetheless, this article is focused solely on private employers who may, as non-governmental entities, regulate the speech of their employees without running afoul of the First Amendment. Thus, it is essentially a non-issue when discussing Title VII's view on this matter. See Fogarty v. Boles, 121 F.3d 886, 890-91 (3d Cir. 1997) ("It must be remembered that the First Amendment applies only to public employers, and there is no doubt that government has a greater right to limit the speech of its employees than it does a private citizen."); Urgent v. Hovensa, L.L.C., No. 2006/0105, 2008 WL 4526677, at *7 (D.V.I. Oct. 2, 2008) (granting motion to dismiss First Amendment claims because "[d]efendant is a private employer rather than a state actor and its actions as described in Plaintiff's Complaint do not constitute state action under the law"); Fraser v. Nationwide Mut. Ins. Co., 135 F. Supp. 2d 623, 643 (E.D. Pa. 2001) (quoting 11 West's Pa. Forms $\S 5.15$ ) ("[C]onstitutional protection of free speech is not generally applicable to private employers."), aff'd in part, rev'd in part, 352 F.3d 107 (3d Cir. 2003), remanded to 334 F. Supp. 2d 755 (E.D. Pa. 2004).

8. Ash v. Tyson Foods, Inc., 664 F.3d 883, 887-88 (11 th Cir. 2011). 
why courts cannot overlook context when dealing with language in discrimination cases. Part III will explore examples of courts' failures to deal realistically with language in employment discrimination cases and will consider the Ash $v$. Tyson case as an example of the tortured approach to language that has resulted from the Supreme Court's failure to give robust guidance on this issue. Part III will also consider potential reasons for the development of this problem and responses to courts that are unwilling to tackle it due to the language of antidiscrimination statutes. Finally, Part IV will suggest a solution to the current problem of language in discrimination cases and will, of necessity, highlight the weaknesses inherent in this solution and possible bases for future study.

I.

\section{THE BURLINGTON CASE AND ITS CULTURAL COMPANIONS}

The details of the incident in Burlington, which centers on the use of the word "nigger" by a white television anchor, are somewhat complicated and puzzling. Mr. Burlington's use of the word during a newsroom meeting came in response to a reporter colleague's description of a story she had covered involving the NAACP's symbolic funeral for the word, ${ }^{9}$ an event the organization held in an attempt to convince people of all races to stop using the word. ${ }^{10}$ In response to the reporter's description, in which she specifically referred to the word as "the n-word," Mr. Burlington said, "Does this mean that we can finally say the word "nigger'?"11 The statement itself is perplexing, given that the story focused on the NAACP's efforts to eradicate the word entirely. In addition, Mr. Burlington's explanation of his intentions did little to explain the matter; he claimed that he was merely expressing the belief that refusing to use the word gave it more power. ${ }^{12}$

Thereafter, the meeting continued to its natural conclusion. While his colleagues did not probe the issue in the moment, one colleague expressed some shock and offense before continuing the meeting. ${ }^{13}$ It was only after the meeting that Mr. Burlington's co-anchor, an African American woman, informed him that his comment caused unrest and that he needed to apologize. ${ }^{14}$ Mr. Burlington then conversed individually with each

9. See Burlington, 759 F. Supp. 2d at 584-85; see also Def.'s Mot. for Summ. J at 6, Burlington v. News Corp., 759 F. Supp. 2d 580 (E.D. Pa. 2010) (No. 2:09-cv-1908).

10. See Corey Williams, NAACP Symbolically Buries N-Word, WASH. POST, July 9, 2009, http://www.washingtonpost.com/wp-dyn/content/article/2007/07/09/AR2007070900609.html.

11. Burlington, 759 F. Supp. 2d at 585 .

12. See Def.'s Mot. for Summ. J, supra note 9, at 8 .

13. See Burlington, 759 F. Supp. $2 \mathrm{~d}$ at 585 .

14. See id. 
employee who was at the meeting and attempted to explain his comments, using the word several more times in these conversations. ${ }^{15}$

When management learned of the incident, it took a number of steps that ultimately lead to Mr. Burlington's termination. Initially, management conducted an investigation and based on the results, required $\mathrm{Mr}$. Burlington to undergo sensitivity training. In the interim, however, the incident leaked to the press and became the subject of multiple articles in newspapers and blogs throughout the Philadelphia region. ${ }^{16}$ At that point, the station decided to take Mr. Burlington off the air permanently and not to renew his contract. ${ }^{17} \mathrm{Mr}$. Burlington argued that the station effectively terminated him, and he later filed his reverse race discrimination claim in federal district court in Philadelphia. ${ }^{18}$

Somewhat surprisingly, neither party addressed in briefing or oral argument the meaning of language and the impact of the racial, gender, or other identity of the speaker on that meaning, even though the incident seemingly brought the issue squarely to the forefront. More specifically, neither party briefed the question whether Title VII permitted an employer to consider the race of an employee who used a racial slur or term. Burlington's attorneys presumably considered it a given that Title VII precluded such consideration because it would mean treating employees differently based on race. The station, on the other hand, did not argue that it was in fact permissible to consider the race of a speaker in making a termination decision. In fact, the bare language of Title VII would make such an approach a rather unlikely path to success.

Nonetheless, perhaps seeing it as the elephant in the room, the trial judge chose to address the issue head-on in his summary judgment opinion. Acknowledging first that this was an issue that had not been decided by the federal courts, the District Court framed the question fairly narrowly: "Can an employer be held liable under Title VII for enforcing or condoning the social norm that it is acceptable for African Americans to say 'nigger' but not whites?"19 Finding that the language of Title VII clearly made it unlawful to treat whites differently from blacks, the court wondered if this particular circumstance justified a deviation from that conclusion. ${ }^{20}$ Despite acknowledging that the racial slur in question is a word with varied meanings, the court nevertheless refused to "conclude that this is a

\footnotetext{
15. Id.

16. See Burlington, 759 F. Supp. 2d at 588; see also Def.'s Mot. for Summ. J, supra note 9, at 12-

17. See id. at 14-15.

18. See Burlington, 759 F. Supp. 2d at 584 .

19. Id. at 596.

20. See id.
} 13. 
justifiable reason for permitting [an employer] to draw race-based distinctions between employees" and, more importantly, refused to interpret Title VII "in accordance with prevailing social norms." 21

The fact that Burlington's use of the slur was not directed at anyone in particular merits some discussion. In the typical employment discrimination case involving the term, an African American employee is the target of the slur and, as a result, claims either that he was subject to a hostile work environment or that he faced some other adverse employment action. ${ }^{22}$ In this context, the use of the slur is evidence that the adverse action was a product of racism. In Burlington, by contrast, a white news anchor spoke the word aloud in a room full of white and African American colleagues but did not direct it at anyone. The white employee was then disciplined and claimed protection under Title VII's reverse race discrimination jurisprudence. Although this distinction would be highly relevant in a hostile work environment case brought by the "target" of the slur, the targeted or non-targeted use of the word is merely one contextual factor among many that I argue courts should consider in interpreting discriminatory language. As used by Burlington, the meaning of the term "nigger" was a function of the history of that word, Burlington's racial identity, his position in the newsroom, his prior relationship with the listeners, the way in which he used the word, and many other contextual factors that determine whether a Title VII violation occurred. I argue that courts have consistently failed to pay due attention to these factors, instead looking for some objective meaning of words that does not exist. Accordingly, courts fail to reach the right outcome in cases like these-or, as underscored by Ash v. Tyson, do so only through a tortured judicial process.

Notwithstanding Burlington's non-targeted use of the slur, his comments were considered highly offensive by some and, Burlington argued, would have been met with an entirely different reaction had he been African American. As the next section will describe, although Burlington is different from most employment discrimination suits involving the slur, it is an increasingly common scenario in the extra-legal world.

\section{A. Similar Incidents Among Celebrities and Ordinary Citizens}

Although Burlington is the first to bring the issue of out-group ${ }^{23}$ use of a racial slur to before a judge or jury, the facts of the case feel somewhat

\footnotetext{
21. Id. at 597 .

22. See KENNEDY, supra note 5, at 88-89.

23. In contrast to common usage, the "out group" in this scenario is typically the majority group, whereas the "in group" is the minority group or the targeted group which has "reclaimed" the derogatory
} 
familiar given the numerous celebrities and ordinary citizens who in recent years have engaged in similar conduct and then faced public outcry. Perhaps the most notable person in recent years to have used the term is Dr. Laura Schlessinger, the white female radio talk show host, who used the word numerous times on her radio show in August 2010. Schlessinger used the word during a conversation with a black female caller who called to complain about her white husband's failure to respond to the use of the word by his friends and family. Schlessinger responded by saying: "Black guys use it all the time. Turn on HBO, listen to a black comic, and all you hear is nigger, nigger, nigger. . . . I don't get it. If anybody without enough melanin says it, it's a horrible thing. But when black people say it, it's affectionate. It's very confusing."24

Schlessinger apologized the next day for what news sources began referring to as her "N-word Rant." 25 She defended her ability to express the sentiments she conveyed but apologized for her use of the full word and noted several times that she was "wrong." 26 One week later, presumably recognizing that the public outcry and negative publicity was not letting up, Schlessinger announced that she was ending her radio show. In contrast to her earlier "apology," Schlessinger explained her decision as follows:

My contract is up for my radio show at the end of the year and I've made the decision not to do radio anymore. The reason is I want to regain my First Amendment rights. I want to be able to say what's on my mind and in

slur and made it an acceptable term to use among those who are targets of it. See Robin Brontsema, $A$ Queer Revolution: Reconceptualizing the Debate Over Linguistic Reclamation, 17 COLO. RES. IN LINGUISTICS 1, 7-16 (2004).

24. Jeremy Holden, FULL AUDIO: Dr. Laura Schlessinger's $N$-word rant, MEDIA MATTERS FOR AMERICA BLOG (Aug. 12, 2010, 7:02 PM), http://mediamatters.org/print/blog/201008120045. The conversation later continued:

CALLER: Is it OK to say that word? Is it ever OK to say that word?

DR. LAURA: It depends how it's said. Black guys talking to each other seem to think it's ok. CALLER: But you're not black, they're not black, my husband is white.

DR. LAURA: Oh, I see, so a word is restricted to race. Got it. Can't do much about that.

CALLER: I can't believe someone like you is on the radio spewing out the $n^{* * * * *}$ word, and I hope everybody heard it.

DR. LAURA: I didn't spew out the $n^{* * * * *}$ word!

CALLER: You said " $n * * * * *, n^{* * * * *}, n^{* * * * * "}$ and I hope everybody heard it.

DR. LAURA: Yes they did, and I'll say it again: $n^{* * * * *}, n^{* * * * *}, n^{* * * * *}$ is what you hear on HBO.

[Crosstalk]

DR. LAURA: Why don't you let me finish a sentence? Don't take things out of context. Don't NAACP me, leave them in context.

Id.

25. Danny Shea, Dr. Laura To END Radio Show After $N$-Word Rant, THE HUfFINGTON POST, Aug. 17, 2010, http://www.huffingtonpost.com/2010/08/17/dr-laura-to-end-radio-sho_n_685652.html.

26. Danny Shea, Dr. Laura's $N$-Word Rant: Radio Host Apologizes For Offensive Language, THE HufFington POST, Aug. 12, 2010, http://www.huffingtonpost.com/2010/08/12/dr-lauras-n-word-rantrad_n_680680.html?ref=dr-laura. 
my heart and what I think is helpful and useful without somebody getting angry, some special interest group deciding this is the time to silence a voice of dissent and attack affiliates, attack sponsors. I'm sort of done with that. ${ }^{27}$

Although Schlessinger's "First Amendment rights" were not actually implicated by this incident ${ }^{28}$ or by the public outcry that resulted, her emotional response was evident-she believed it to be unfair that she, as a white woman, could not say the word without eliciting widespread outrage. Although she was not technically fired, Schlessinger's remarks suggest that, had she been fired, she would have considered herself a victim of reverse race discrimination, like Burlington.

In addition to Burlington and Schlessinger, several other celebrities have discovered the immediate and emotional response that often follows a white person's use of the word. John Mayer, ${ }^{29}$ a popular singer, Seinfeld's Michael Richards, ${ }^{30}$ and Barbara Walters are some of the more recent examples. In each, the public response focused on the racial identity of the speaker, which altered the meaning of the word. Sherri Shepherd, an African American host of the television show The View, articulated this point most clearly in her response to the use of the word by Whoopi Goldberg and Barbara Walters when they discussed then-presidential candidate Rick Perry's hunting camp, which was apparently called "Niggerhead." Shepherd said to Goldberg, "When I heard you say it, it was fine." But, turning to Walters, she stated, "I didn't like the way you said it." "It's because I'm white?" Walters asked. Shepherd then responded that it was: "It's something about hearing you say it. ... [W] [Wen you say it it's a different connotation." 31

27. Danny Shea, Dr. Laura To END Radio Show After N-Word Rant, supra note 25.

28. See supra note 7.

29. John Mayer used the term nigger in an interview with Playboy magazine, in which he told the interviewer: "Someone asked me the other day, 'What does it feel like now to have a hood pass?' And by the way, it's sort of a contradiction in terms, because if you really had a hood pass, you could call it a nigger pass." Rosie Swash, John Mayer Apologises After Using N-Word In Playboy Interview, THE GUARDIAN, Feb. 11, 2010, http://www.guardian.co.uk/music/2010/feb/11/john-mayer-playboyinterview. Mayer later apologized, posting on Twitter: "I am sorry that I used the word. And it's a shame that I did because the point I was trying to make was the exact opposite spirit of the word itself. It was arrogant of me to think I could intellectualise [sic] using it, because I realize there's no intellectualizing a word that is so emotionally charged." Id.

30. Michael Richards used the word when a group of African Americans began to heckle him during a stand-up comedy routine. Associated Press, Richards Says Anger, Not Racism, Sparked Tirade, TODAY CELEBRITIES (NOV. 22, 2006, 9:33 PM), http:/today.msnbc.msn.com/id/15816126/ns/todayentertainment/t/richards-says-anger-not-racism-sparked-tirade/\#. A comedian who was at the comedy club during Richards' performance commented: "Once the word comes out of your mouth and you don't happen to be African-American, then you have a whole lot of explaining." Id.

31. Jack Mirkinson, Barbara Walters' Use of N-Word Leads to Tense Discussion with Sherri Shepherd, THE HUFFINGTON POST, Oct. 3, 2011, http:/www.huffingtonpost.com/2011/10/03/barbara- 
While the controversy surrounding use of the term by media personalities and celebrities dominates the news, examples abound among average citizens, as well. Since the 1990 s, there have been close to ten similar occurrences around the country in which a member of a majority group faced demotion, termination, or like discipline by an employer for using a derogatory slur that, when spoken by a member of the targeted group, may not have raised any eyebrows. ${ }^{32}$ These incidents seem to occur with even more regularity in the educational context. In the last four years alone, there have been at least three such incidents at the college, high school, and middle school levels in addition to several others that occurred in the 1990's. ${ }^{33}$

In each of these cases, it was the speaker's identity that led to the outrage over the use of the discriminatory language. And, while celebrities' use of a slur typically leads to public outcry followed by an attempt at an image-saving apology, the end result is usually termination for ordinary Americans in the employment context. Burlington differed from these other cases only in his willingness to challenge his termination and claim in court (rather than merely to family, friends or the media) that he was a

walters-n-word-view_n_992656.html; see also Beenish Ahmed, "S- - - White Girls Say" Parody: Offensive or Funny?, NATIONAL PUBLIC RADIO (Jan. 12, 2012), available at http://www.npr.org/2012/01/12/145101169/stuff-white-girls-say-offensive-or-funny (discussing a web parody by video blogger, Franchesca Ramsey, who takes on the persona of a white woman and asks, among other things, why she can't say the N-word).

32. See Chris Erikson, "Pink slip" at 82, NEW YORK POST, Mar. 7, 2011, http:/www.nypost.com/p/news/local/queens/pink_slip_at_MOZ5751swgmYDMmAS8SVWK

(describing a heterosexual American Airlines worker who was terminated after using the term faggot when discussing the military's "Don't Ask Don't Tell" policy with co-workers); Words on Facebook Cost Bourne Firefighter His Job, WHDH-TV 7 NEWS (Feb. 25, 2011, 11:20 AM), http://wwwl.whdh.com/news/articles/local/capeandislands/12003630380176/words-on-facebook-costbourne-firefighter-his-job/ (describing a firefighter in Massachusetts who was terminated after he used anti-gay slurs in a posting on Facebook).

33. See, e.g., White Towson Prof Fired for Using the N Word, WOMANIST MUSINGS (March 4, 2010), http://www.womanist-musings.com/2010_02_28_archive.html (telling story of Towson professor, Allen Zaruba, who had been discussing a book about identity and the body in his art class when he referred to himself as a "nigger on the corporate plantation"-ironically intending to highlight his status as an adjunct professor who, absent tenure, could be fired at any time); Marshall Zelinger, Mullen Fires Teacher Who Used 'N-Word', THE DENver ChANnEL (Sept. 23, 2010, 5:23 PM), $\mathrm{http}: / / \mathrm{www}$.thedenverchannel.com/news/25136886/detail.html; Teacher suspended for using $N$ word to describe Obama, THE DAILY VOICE (Oct. 3, 2008, 1:58 PM),

$\mathrm{http} / /$ thedailyvoice.com/voice/2008/10/teacher-fired-for-using-n-word-001200.php (discussing teacher Greg Howard who, referring to then-candidate Barak Obama's campaign, reportedly asked his class what "CHANGE" stood for and proceeded to write out the acronym on the board, writing "Come Help A Nigger Get Elected"). See also KENNEDY, supra note 5 at 142-48 (discussing a coach at Central Michigan University and an adjunct professor at Jefferson Community College who were both fired in the 1990s after using the word nigger with students); Dambrot v. Cent. Mich. Univ., 55 F.3d 1177, 1185 (6th Cir. 1995) (denying former head coach from Central Michigan University's claim that his termination violated his First Amendment rights). 
victim of reverse race discrimination. In addition to demonstrating the prevalence of the issue, these examples illustrate employers' willingness to discipline employees for their use of discriminatory language and particularly slurs. In most instances, however, these disciplinary decisions resulted from public outrage that responded largely to the context of usage, including the race of both the speaker and the listeners.

\section{B. Identity and Discriminatory Language in Popular Culture}

The notion that a white person may be penalized for using the term "nigger" while his African American co-worker might not face the same discipline may seem an unfair double standard to some, but to many, it is an acceptable reality of living in a multicultural society. In fact, it is precisely because of both the widespread acceptance of this reality and the coexisting suggestion of unfairness that this purported double standard has become a focus of comedic and dramatic forms of popular entertainment.

In the last several years, the notion that only those members of the "ingroup" or targeted group can use discriminatory language has been the subject of high- and low-brow entertainment alike. For example, it has been the butt of jokes in the wildly popular animated series, "South Park," which devoted an entire episode to the issue entitled "Birth of the N-Word Guy." 34 Additionally, Tina Fey used the notion for comedic purposes on "30 Rock." 35 The prevalence of perceived "in-group" and "out-group" differences regarding use of discriminatory language makes this issue a source of humor.

The acknowledgment of this reality is not limited to comedy. HBO's series "Treme" about post-Hurricane Katrina New Orleans dealt with the issue in a more serious way. In an early episode, the character of Davis McAlary, a white musician, DJ, and activist, used the word "nigger" in a bar in the Treme, a largely African American neighborhood that he loves

34. South Park: Birth of the N Word Guy (Comedy Central television broadcast Mar. 7, 2007), available at http://www.southparkstudios.com/clips/104296/birth-of-n-word-guy\#searchterm=nword\% 20guy. In the episode, a white man is labeled "the Nigger Guy" by a stand-up comedian for having previously said the word on television.

35. 30 Rock: Argus (NBC television broadcast April 29, 2010) (presenting a scene in which her character, a white woman, reads aloud from a letter between two African American men, Fey reads, "I will always be your ... oh no, I'm white, l can't read that word"); see also GET HIM TO THE GREEK (Universal Pictures 2010), available at http:/www.youtube.com/watch? $\mathrm{v}=4$ _Anuo4_Tlo\&feature =related (presenting a scene in which Sean Combs, playing an African American record label executive, discusses the song "African Child" with Jonah Hill, who plays a white low-level employee. Hill asks Combs if he likes the song. Combs responds, "Hell, fucking no. It's the most racist condescending shit ever made. What the fuck you calling me, a house nigga?" In one of the movie's more astute and amusing moments, Hill responds in a somewhat meek voice, "No, I don't think you're a house n-word," acknowledging his out-group status and the resulting limits on his ability to use a racial slur). 
and feels a part of. ${ }^{36}$ When his comment was met with the anger of a black patron, McAlary attempted to justify his comments, saying, "It's OK man, I live in this neighborhood," as if his residence in the Treme made him a member of the group who can use the word. Ultimately, McAlary's friends tried to silence him, but when that failed, he took a "violent punch to the jaw." "37 Once again, the show illustrated that it is not a speaker's intentions in using the word that matter, nor is it his or her view of himself that determines listeners' responses to the utterance of a racial slur. As Rachel Brown commented in the Atlantic Monthly: "Does this guy actually think he's black? Or that it doesn't matter if he isn't?"38 The primary factor in determining whether use of the slur will be acceptable or met with outrage or even violence is the context of the use, including the racial identity of the speaker.

While these are but a few examples of the treatment of the issue in popular culture, all of these instances underscore that words are deemed acceptable or off-limits based upon the identity of the speaker, largely as a result of race relations in America. Although most of the foregoing examples involve the term "nigger," the cultural and linguistic phenomenon is equally applicable to numerous forms of discriminatory language. As the courts in Ash v. Tyson discuss, the term "boy," when used by a white person and directed at a black man, is decidedly derogatory and racist, yet it is benign in other contexts. ${ }^{39}$ Similarly, the terms "fag" and "faggot," when used against homosexuals, and "cunt" or "bitch," when used against women, are derogatory and indicate significant bias. But when used by a member of the "in group" in a particular situation, time, and context, these words can embody wholly different meanings and purposes. ${ }^{40}$ In fact, the ability of these words to take on new meanings in various contexts is both an extraordinary and troublesome feature of modern language. In the mouths of members of the targeted group, these words can be terms of

36. See Aymar Jean Christian, Why Do l Hate Steve Zahn's Davis in 'Treme'?, RaCialicious (April 27, 2010), http://www.racialicious.com/2010/04/27/why-do-i-hate-steve-zahn\%E2\%80\%99sdavis-in-\%E2\%80\%98treme $\%$ E2\%80\%99 (discussing how McAlary established his view of himself as a part of the neighborhood in an encounter with his white homosexual neighbors, whom he despises because of their apparent attempt to gentrify the neighborhood. McAlary, in a fit of exasperation, states, "This is the Treme dude! The most musically important black neighborhood in America.... [D]id you know that?").

37. Rachael Brown, 'Treme': Desperately Seeking a Story Line, THE ATLANTIC, May 10, 2010, $\mathrm{http}: / \mathrm{www}$. theatlantic.com/entertainment/archive/2010/05/treme-desperately-seeking-a-storyline $/ 56445 /$.

38. Id.

39. See Ash v. Tyson Foods, Inc., 664 F.3d 883, 888 (11 th Cir. 2011).

40. See Brontsema, A Queer Revolution, supra note 23, at 7-16 (discussing the reclamation of the terms queer, dyke, nigger, and cunt by members of the "in group" while the words retain their pejorative meaning when used by others). 
endearment, ironic statements mocking institutions of power, or political statements meant to suggest a refusal to submit to the dominant culture's values and conventions. But when spoken by an outsider, these words become weapons of sorts, often meant to threaten, harass, intimidate, or belittle their target. Even when these words are not specifically directed at a member of the target group, those who hear it often feel threatened or even harmed by the mere use of the word in their presence. ${ }^{41}$

\section{The Complexities of the $\mathrm{N}$-Word and Other Slurs}

As the foregoing examples suggest, words carry different meanings depending on numerous contextual factors including the racial or other identity of the speaker and listener. But linguistic meaning is tied not merely to the race of the parties involved, but also to socioeconomic class, educational level, country of origin, and cultural community. As a result, the term "nigger" has varied meanings within the African American community itself. ${ }^{42}$

The meaning of the slur is particularly impacted by the age of the speaker and listeners. Kennedy describes this phenomenon when explaining his own experiences with the word:

Big Mama (Kennedy's grandmother) peppered her speech with references to "niggers" by which she meant discreditable Negroes. . . . If Big Mama said that a person had acted like a nigger, it could only mean that, in her view, someone had behaved badly. By contrast, when my cousins and their friends said that someone had acted like a nigger it might mean that that person had reacted to racist challenge with laudable militancy. ${ }^{43}$

And, he notes, generational differences within the African American community impact the use and meaning of the term as well. "[W]hile some

41. See Mari J. Matsuda, Public Response to Racist Speech: Considering the Victim's Story, 87 MICH. L. Rev. 2320, 2336-41 (1989) (citing Patricia Williams, Spirit-Murdering the Messenger: The Discourse of Fingerpointing as the Law's Response to Racism, 42 U. MIAMI L. REV. 127, 129 (1987)) ("The negative effects of hate messages are real and immediate for the victims. Victims of vicious hate propaganda have experienced physiological symptoms and emotional distress ranging from fear in the gut, rapid pulse rate and difficulty in breathing, nightmares, post-traumatic stress disorder, hypertension, psychosis, and suicide. Professor Patricia Williams has called the blow of racist messages 'spirit murder' in recognition of the psychic destruction victims experience.").

42. See Brontsema, supra note 23, at 7 ("Far from being restricted solely as a derogation that maintains racial subordination, Smitherman identifies seven contemporary, in-group uses of nigga (as opposed to nigger, often associated with out-group usage): 1) close friend, backup 2) someone who is culturally Black 3) synonym for Blacks or African-Americans 4) African American women's term for the Black man as lover/partner/significant other 5) rebellious, fearless, unconventional, in-yo-face Black man 6) derogatory, similar to pejorative use by out-group 7) any cool, down person who is deeply rooted in hip hop culture.")

43. RaNDALl KenNedy, Introduction to Nigger: THE StRange CareER of a Troublesome WORD Xv, xvii (2003). 
of my younger relatives are adamantly opposed to any use of nigger, believing it to be only and unalterably a debasing slur, some of my older relatives anticipated by many years the transformation of nigger (or "nigga") that is now widely attributed to hip hop culture." side, as A Tribe Called Quest makes clear in their song, "Sucka Nigga," it is often younger African Americans who feel more comfortable using the word as a term of political resistance and as a term of endearment, sometimes to the dismay of their older relatives. ${ }^{45}$

Adding an additional layer of complexity, the speaker's country of origin also impacts his or her view of the word and the perception of others about its meaning. This is true both within the African American community and beyond it. As Carol Motley and Kellina Craig-Henderson noted in their study on the meaning of the term and reactions to it among blacks of various ethnic origins, African Americans attached greater significance to the in-group or out-group status of a person who uses the word than did the foreign-born blacks. ${ }^{46}$ In addition, one can only assume that non-black immigrants to the United States may perceive the word differently and express different meanings than their American-born counter-parts. Immigrants who have no intimate knowledge of segregation or the Civil Rights Movement and whose only knowledge of the word comes from hip hop or rap lyrics may be attempting to express meanings of the word typically reserved for in-group members.

Of course, this linguistic phenomenon is not limited to the n-word. For example, within the gay community, slurs have been alternately viewed as oppressive, harmful, or celebrated words depending on time, culture, and the particular identity of the individual speaker. As George Chauncey describes in his history of the gay community in New York, "While the terms queer, fairy, and faggot were often used interchangeably by outside observers (and sometimes even by the men they observed), each term also

44. Id. at xxvii.

45. See A Tribe Called Quest, Sucka Nigga, Midnight MARAUders (RCA Records 1993), lyrics available at http://www.metrolyrics.com/sucka-nigga-lyrics-a-tribe-called-quest.html\#ixzz21Yd1xf85. ("See, nigga first was used back in the Deep South/ Fallin' out between the dome of the white man's mouth/ It means that we will never grow/ You know the word dummy/ Other niggas in the community think it's crummy/ But I don't, neither does the youth 'cause we/ Embrace adversity, it goes right with the race/ And being that we use it as a term of endearment/ Niggas start to bug to the dome/ ls where the fear went/ Now the little shorties say it all of the time/ And a whole bunch of niggas throw the word in any rhyme.").

46. Carol M. Motley \& Kellina M. Craig-Henderson, Epithet or Endearment? Examining Reactions Among Those of the African Diaspora to an Ethnic Epithet, 37 J. OF BLACK STUD. 944, 956 (2007). 
had a more precise meaning among gay men that could be invoked to distinguish its object from other homosexually active men." ${ }^{\circ 7}$

The point is clear: linguistic meaning, particularly of derogatory terms, is a complex phenomenon that results from a multitude of contextual factors. These factors include time, place, identity of the parties, and tone of voice. Although racial or gender identity may only be the tip of the iceberg in terms of meaningful identity factors, contextual factors cannot be ignored in determining linguistic meaning. The following Part elaborates further on the consideration of these factors in interpreting language, what I call a "context-driven theory of language."

II.

\section{The Context-Driven MEAning of LANGUage}

\section{A. Linguistic Power}

In most cultures, language has the power to impact interpersonal relations, power structures, and the successes and failures of the members of a society. Language can "label, construct, suppress, and control people by use of metaphor." 48 As Michael Coyle describes, "language can be used to justify human action, such as defining others in ways that permit and encourage their social control." ${ }^{49}$ Haig Bosmajian further explains the power of language:

[T] he languaging of Native Americans as 'uncivilized barbarians,' African Americans as 'beasts' or 'nonpersons,' European Jews as 'vermin,' 'parasites,' and 'a plague,' along with similar implications for persons through the language of sexism, homophobia, and the language of war, gives legal and moral standing to efforts to criminalize and control such populations. ${ }^{50}$

Even legal scholar Franklyn Haiman, who opposes the criminalization of hate speech as a First Amendment violation, acknowledges the deleterious effects of language on the human psyche:

47. George Chauncey, GAY NEW YORK 15-16 (1994). Chauncey explains further that "[t]hey might use queer to refer to any man who was not "normal" but they usually applied terms such as fairy. faggot, and queen only to those men who dressed or behaved in what they considered to be a flamboyantly effeminate manner. They were so careful to draw such distinctions in part because the dominant culture failed to do so." See also Andrea Carnaghi \& Anne Maass, In-Group and Out-Group Perspectives in the Use of Derogatory Group Labels: Gay Versus Fag, 26 J. OF LANGUAGE AND SOC. PSYCHOL. 142, 142 (2007).

48. Michael Coyle, Notes on the Study of Language: Towards Critical Race Criminology, $11 \mathrm{~W}$. CRIMINOLOGY REV. 11, 13, 15 (2010).

49. Id.

50. Id. at 15 . 
Being that target of denigrating words and symbols or of ideas that plant the seeds of group hatred may be psychologically frightening, may cause one to feel intimidated even in the absence of a direct and immediate threat of physical harm, may stimulate feelings of self-doubt and second-class citizenship, and may lead to one's psychological withdrawal or physical escape from the environment in which the hate speech has occurred. ${ }^{51}$

Linguistic anthropologists have, for decades, considered language so powerful that its use can be considered an act itself. J.L. Austin, a British philosopher, first described the concept of "speech acts" in the 1960s in his seminal lectures titled How to Do Things with Words. ${ }^{52}$ He coined the terms "performative sentence," "performative utterance," and "performative verb" ${ }^{\text {"53 }}$ to argue that merely saying something is actually doing something. ${ }^{54}$ As Austin explained, "[T]he issuing of the utterance is the performing of an action." 55 He recognized that the speaking of words, without any act, can "make things happen, bring nonexistent states of affairs into being." Austin's examples are simple: a couple that says "I do" at the alter accomplishes the act of marrying through their words, a dying man transmits his property by the words "I give and bequeath," and a betting man risks actual money simply by saying "I bet you.""

This concept, although quite simple, has far-reaching implications. While Austin's examples are straightforward and arise when the speaker uses relatively benign words and intends the non-objectionable action that his words induce, speech acts can also occur under more insidious circumstances. Some speakers aim not to accomplish a particular action, but rather to create an emotion, demonstrate power or weakness, or subjugate others. There is "another kind of speech act [that] takes a more devious route to do what it does, masquerading as something else. It uses the language of a constative statement in order to effect an action without explicitly saying so." 58

Derogatory slurs are one example of a negative and harmful "speech act," but otherwise nonthreatening words can also transform into malevolent speech acts under the right circumstances. Claudia Brodsky LaCour argues that Clarence Thomas's use of the term "racism" during his Supreme Court confirmation hearings was just such an act. By saying that

51. Franklyn S. Haiman, "SpeEch ACts" and the First AmEndment 27 (1993).

52. J.L. AUSTIN, HOW TO Do THINGS WITH WORDS 6-7 (1962).

53. Id. at 6 .

54. Id. at 6-7.

55. Id. at 7 .

56. Claudia Brodsky LaCour, Doing Things with Words: "Racism" as Speech Act and the Undoing of Justice, in RACE-ING JUSTICE, EN-GENDERING POWER 127, 134 (Toni Morrison ed., 1992).

57. AUSTIN, supra note 52, at 5.

58. LaCour, supra note 56, at 134-35. 
word under those circumstances, Thomas was able to shut down all other discussion and re-direct the focus of the entire country-and more importantly, his questioners-from accusations against him of sexual harassment to the racial implications of accusing an African American man of sexual impropriety. ${ }^{59} \mathrm{He}$ accomplished this despite the fact that his accuser was an African-American woman. The use of that term would have had none of those insidious "speech act" qualities under different circumstances. Had the majority of senators questioning Thomas not been white, his use of the term "racism" to characterize the event would have carried far less weight. ${ }^{60}$

\section{B. Context as Driver of Meaning}

Derogatory slurs and epithets have a particularly injurious quality that is unlike other types of speech. "The experience of being called 'nigger', 'spic', 'Jap', or 'kike' is like receiving a slap in the face. The injury is instantaneous." 61 But words are not powerful in a vacuum. They carry meaning and an ability to empower or harm based on the context in which they are spoken or used.

One aspect of context-driven meaning is the notion that a word has power because of meaning it has derived over the course of history. Essentially, injurious words can cause immediate, severe damage and actual injury because they carry historical meaning-typically, a history of actual discrimination, oppression, and violence. In saying such a word, the speaker embodies past oppressors who have used that language. Such words "evoke in the target all the millions of cultural lessons regarding her

59. This is true even though the racism to which Thomas referred connotes the history of black men being accused of rape and other sexual crimes by white women, a context dramatically different from Anita Hill (a black woman) accusing him of sexual harassment. See Andrew Goldman, Anita Hill's Long Memory, N.Y. TIMES MAGAZINE, Oct. 2, 2011, http://www.nytimes.com/2011/ 10/02/magazine/talk-anita-hills-long-memory.html.

60. LaCour also argues that Thomas's initial use of sexually harassing words (as detailed in Hill's accusations) were speech acts as well. "In recounting details of pornographic films, in describing himself as an unsung star of the genre, and in insisting over and over that Hill would want to see such films, would want to 'see' him, he was attacking her psyche, forcing her to see him as 'Giant'. . Without attacking, even touching her body, he was murdering with words, killing whatever was free in her, free to believe she had the liberty to do and imagine what she wanted." LaCour, supra note 56, at 148.

Catherine MacKinnon has similarly argued that oppressive language is powerful because of its ability to itself create action. "Social inequality is substantially created and enforced-this is, donethrough words and images. Social hierarchy cannot and does not exist without being embodied in meanings and expressed in communications. ... Elevation and denigration are all accomplished through meaningful symbols and communicative acts in which saying it is doing it." CATHERINE A. MACKINNON, ONLY WORDS 13 (1993).

61. HAIMAN, supra note 51, at 28 (quoting Charles R. Lawrence III, If He Hollers Let Him Go: Regulating Racist Speech on Campus, 1990 DUKE L. J. 431, 452, 461 (1990)). 
inferiority that she has painstakingly repressed, and imprint upon her a badge of servitude and subservience for all the world to see." ${ }^{62}$ As Judith Butler has observed:

[W] hy do the names that the subject is called appear to instill the fear of death and the question of whether or not one will survive? Why should a merely linguistic address produce such a response of fear? Is it not, in part, because the contemporary address recalls and reenacts the formative ones that gave and give existence?

If a performative [speech act] provisionally succeeds... then it is not because an intention successfully governs the action of speech, but only because that action echoes prior actions, and accumulates the force of authority through the repetition or citation of a prior authoritative set of practices. $" 63$

With respect to derogatory slurs in particular, she notes, "[t] he speaker who utters the racial slur is thus citing that slur, making linguistic community with a history of speakers." 64

This notion of historical meaning is but one aspect of the contextdriven nature of language. As discussed above, there are numerous contextual factors that contribute to the meaning of spoken language, including the position and relationship of the speaker and listeners. Even Franklyn Haiman, in taking issue with the notion of "speech acts" for purposes of criminalizing speech, acknowledges this point. In arguing that words do not change reality, but that people do, Haiman observes that it is the position of the speaker that is essential. "[T]here are a large number of illocutionary acts that require an extra-linguistic institution, and generally a special position by the speaker and hearer within that institution in order for the act to be performed." 65 Haiman offers several examples to illustrate this point. When an umpire yells the words "You're out!" to a player during a ball game, those words have specific meaning because of the position of the umpire and the context of the speech. The words alone affect reality-the player is indeed "out" and must leave the field-but only because the official position of the umpire insures that his words will be obeyed. ${ }^{66}$ These words become "speech acts" only by virtue of contextual factors.

Similarly, Haiman argues that language becomes legally actionable only when context and relational factors require it.

62. Id.

63. JUdiTH BUTLER, EXCITABLE SPEECH 5, 51 (1997).

64. Id. at 52. Cf. MACKINNON, supra note 60 , at 59 (discussing a similar effect with sexual terms, noting that words are traumatizing not because of their content, but because of "the experiences they embody and convey").

65. HAIMAN, supra note 51, at 14 (quoting John R. Searle, A Taxonomy of Illocutionary Acts, 5 LANGUAGE IN SOC'Y 1, 349 (1976)).

66. See id. at 12. 
A threat by a 125 -pound weakling to punch out a 250 -pound football player is not the same as the threat of a teenage gang with a history of violence to beat up or kill anyone who enters their turf. . . . In short, the decision whether a credibly threatening message has been sent and received can only be made by evaluating the specific circumstances of a particular interaction. Its meaning and significance can only be understood by taking into account not only the symbolic stimulus, but the mental response of its audience, the relationship of the parties involved, and the context in which it occurs. ${ }^{67}$

Similarly, MacKinnon, toward whom Haiman directs much of his skepticism, agrees that the harm of language is necessarily contextual. Discussing the injury caused by sexual harassment in the workplace, MacKinnon notes that "[t]he harm done by this behavior is importantly contextual, certainly, but it is implicitly recognized that social life occurs only in social context, and this is a social harm." 68

These scholars underscore the importance of context in the development and use of language. In fact, they are not alone. Early linguistic anthropologists observed the fundamental nature of context in learning and translating languages. Bronislaw Malinowski, the first fieldworker anthropologist who, in the early to mid-1900s, learned the language of the people he was studying, created an ethnographic theory of language with two central components: (1) "the notion of context of situation" and (2) the view of language as a mode of action. ${ }^{69}$ Malinowski realized that a word-for-word translation of an expression did not reveal its meaning - not in the way the native speaker understood it. ${ }^{70}$ Instead, "a listener would also need to be informed about the situation in which [certain] words were spoken. He would need to have them placed in their proper setting of native culture."7l

Similarly, Michelle Rosaldo, working in the twentieth century with the Ilongots, a group of hunters and farmers in the Philippines, noted that language is only understandable when the listener or observer understands the social and cultural system in which that language arises and, in turn, reproduces. ${ }^{72}$ She argued that the intentionality behind words is not the key

67. Id. at 17.

68. MACKINNON, supra note 60 , at 48 .

69. See Alessandro DuRANTI, Linguistic ANTHROPOlOGY 215 (1997) (quoting Bronislaw Malinowski). This concept of language as action and the idea that "the main function of language is not to express thought, not to duplicate mental processes, but rather to play an active pragmatic part in human behaviour," is akin to Austin's concept of the "speech act." Compare id. at 216 with AUSTIN, supra note 52 , at $6-7$.

70. See id. at 16.

71. DURANT1, supra note 69 , at 216 (internal quotations omitted).

72. See id. at 233-34. 
to their meaning. ${ }^{73}$ Instead, she focused on the relationship between individuals and speakers, and the relationship between the social and natural world in which speakers operate. ${ }^{74}$ UCLA anthropologist, Alessandro Duranti perhaps best stated the importance of context to the development of language:

[W] could say that language is in us as much as we are in language. By connecting people to their past, present and future, language becomes their past, present, and future... . [F]or linguistic anthropologists the question of the nature of language cannot be separated from the question of the use of language by particular individuals at particular times. The study of language is inherently historical, that is, located in time and with time as one of its fundamental dimensions. ${ }^{75}$

The study of linguistics and feminism has similarly acknowledged the role of context in creating meaning. As Susan Ehrlich and Ruth King point out, "meaning is a matter not only of individual will but of social relations embedded in political structures." "T6 These authors, too, point out that "linguistic forms do not come permanently glued to meanings but are endowed with meanings in the course of social practice." 77

This theory of language as context-driven is unquestionably applicable to the use of language in employment discrimination cases. It is most obviously applicable to the use of derogatory slurs by members of an "outgroup." The slur is a "speech act"-an act with meaning and consequences. In fact, when a white person uses the term "nigger," regardless of his conscious intentions, he is making a fundamental statement about his place in the world and, by extension, the place of African Americans. The history embedded in the term (its exclusive use in the nineteenth century as an assertion of power by whites over their black slaves) combined with the race of the white speaker and black listener is akin to the speaker saying explicitly: "I reject the concept of equality, I reject your humanity, I am more powerful than you, and because of that power, I can say anything I want, and you have no recourse." And the act has that consequence. It typically renders the targeted listeners speechless and often demoralized,

73. See id.

74. See id. at $231-36$.

75. Id. at $336-37$.

76. Susan Ehrlich \& Ruth King, Feminist Meanings and the (De)Politicization of the Lexicon, 23 LANGUAGE IN SOC'Y 59, 60 (1994) (quoting SALLY MCCONNELL-GINET, The Sexual (Re)production of Meaning, in Language, Gender and Professional Writing 35-50 (Francine H.W. Frank \& Paula A. Treichler eds., 1989)).

77. Id. at 74 (quoting Penelope Eckert \& Sally McConnell-Ginet, Think Practically and Look Locally: Language and Gender as Community-Based Practice, 21 ANN. REV. ANTHROPOLOGY 461, 482 (1992)). 
and creates in them a feeling of helplessness that is met with anger, fear, or sadness. $^{78}$

Speech acts find application beyond derogatory slurs, as well. In fact, any word or words, when spoken by a specific person and in a particular context, can have the effects discussed above. It can be equally oppressive for a male supervisor to daily compliment his female subordinate on her clothing as it is for him to call her a "slut."" But neither comment may offend or oppress the employee if spoken by her female co-worker in a context in which her meaning is playful or expresses solidarity. Essentially, what linguistic anthropologists, philosophers, and feminist and legal scholars alike have stressed is the inherent flexibility of language. Words derive meaning from the context in which they are used, including the time and place of their use, as well as the relationships between, and identity of, those involved in the speech.

Nonetheless, despite seemingly widespread agreement among linguists, anthropologists, and philosophers, this understanding of linguistic meaning has eluded or been ignored by courts in discrimination cases. While courts traditionally use context to determine the meaning of a statutory or contractual term, this practice is often abandoned completely when a discriminatory word or phrase is used in the workplace, with courts searching for "simpler" or more "objective" means of determining meaning.

III.

\section{THE MistreatMENT OF LANGUAGE BY COURTS}

That courts tend to ignore the contextual realities of modern language use and even the historical meaning of words when evaluating the discriminatory implications of such language rings true throughout district

78. The notion of the use of language as an act has its detractors. See, e.g., HaIman, supra note 51, at 3-5 (taking issue with the notion that speech can itself be an act and thus punishable as a crime. Haiman's primary concern is that by applying the concept of "speech act" to hate speech and by claiming that this type of speech can be treated as a deed, scholars and prosecutors have been able to bypass the First Amendment's all-important protection of speech). Applying Haiman's approach to slurs in the workplace, however, alters nothing. Haiman is concerned with the government punishing speech and finding a way around constitutional protection. The First Amendment, of course, is not implicated when a private employer chooses to fire an employee for speech. See supra note 7 . Haiman himself acknowledges that certain speech that constitutes sexual harassment should be prohibited in the workplace. See HAIMAN, supra note 51, at 50 ("A . . persistent pattern of talk or gestures coming from a peer or group of peers in a work situation, where the target cannot extricate himself or herself from the scene, ought, after fair warning, to be ... prohibitable.").

79. The power dynamics in a relationship between manager and subordinate render compliments, even if made with benign intention, into a tool of disempowerment. They can make a female subordinate feel as if her standing in the workplace is based on her looks, her clothing, or her sexuality as opposed to her professional accomplishments and contributions. In this way, otherwise benign compliments can have the same force as a slur. 
and appellate court opinions. Perhaps sensing this emerging problem in the lower courts, the Supreme Court devoted two sentences in a three-page opinion in 2006 to the role of language and its meaning in discrimination cases. In Ash v. Tyson Foods, Inc. ${ }^{80}$ the Court addressed the meaning of the term "boy" and its racial implications and reprimanded the Eleventh Circuit for concluding that the word had to be modified by "black" or "white" to have racial meaning. ${ }^{81}$ On language in general, the Court made a single statement: "The speaker's meaning may depend on various factors including context, inflection, tone of voice, local custom, and historical usage." 82

While this statement was surely not a striking pronouncement of any kind, ${ }^{83}$ it was the Court's only attempt (although a feeble one) to point out that language, particularly in discrimination cases, can have meaning beyond a printed word on a page and that it is instead a product of history, culture, and context. But this is all the Supreme Court said about the matter and, as such, it was a missed opportunity of grand proportions given that courts continue to mistreat language by viewing it as divorced from the identity of the speaker and the historical and other contexts in which it is used. This is particularly true in employment discrimination cases, in which language with racist or sexist implications is often present and highly relevant to a finding of bias. ${ }^{84}$

80. 546 U.S. 454 (2006).

81. Id. at 456 ("Although it is true the disputed word will not always be evidence of racial animus, it does not follow that the term, standing alone, is always benign.").

82. $I d$.

83. In fact, it seems to be a mere restatement of an oft-cited quote from Towne v. Eisner where Justice Holmes famously remarked, "A word is not a crystal, transparent and unchanged, it is the skin of a living thought and may vary greatly in color and content according to the circumstances and the time in which it is used." 245 U.S. 418, 425 (1918); see also NLRB v. Federbush Co., 121 F.2d 954, 957 (2d Cir. 1941) ("Words are not pebbles in alien juxtaposition; they have only a communal existence; and not only does the meaning of each interpenetrate the other, but all in their aggregate take their purport from the setting in which they are used, of which the relation between the speaker and the hearer is perhaps the most important part.")

84. See Burlington v. News Corp., 759 F. Supp. 2d 580 (E.D. Pa. 2010). The problem most often presents itself in race cases but has the potential to be far more widespread. In Burlington, the issue is whether the plaintiff's race can be considered by his employers in assessing the import of his use of a racist word. Consider, however, a sexual harassment case in which a male supervisor consistently compliments his female subordinate on her clothing and style. Can that female employee claim she was harassed by her supervisor if the same words from the mouth of a female co-worker would have felt entirely benign but coming from her male boss took on a sexual and harassing tone? Or, consider the same scenario but in jurisdictions in which sexual orientation is a protected category. If the compliments came from a lesbian supervisor to her female subordinate, is the supervisor's sexual orientation relevant to the harassment claim? What if the female employee did not sue but complained to Human Resources, which investigated and terminated the lesbian supervisor-does the supervisor then have a valid claim for discrimination because her comments would have been viewed as benign if not for her sexual orientation? 


\section{A. The Ash v. Tyson Saga}

Ash v. Tyson centered on race discrimination at a Tyson Foods chicken processing plant. The case began in an Alabama federal district court in 1996 and originally involved six plaintiffs who brought multiple claims. At the time of trial, only two plaintiffs Anthony Ash and John Hithon remained, and each brought claims for failure to promote based on race discrimination. ${ }^{85}$ Both Ash and Hithon prevailed, and the jury returned identical awards for each plaintiff. ${ }^{86}$ At that point, Tyson filed a Motion for Judgment as a Matter of Law, arguing, among other things, that the evidence presented at trial was insufficient to sustain the finding that the plaintiffs had been passed over for promotion because of their race.

The plaintiffs pointed to the use of allegedly discriminatory language by Tyson's white male plant manager, the decision maker for promotions, as part of their attempt to show that Tyson's purportedly legitimate, nondiscriminatory reason was merely a pretext for race discrimination. Among the evidence of his racial animus were two incidents in which the plant manager referred to Ash or Hithon, both African Americans, as "boy." Based on the evidence submitted at the trial, the district court agreed with Tyson that the jury verdicts should be overturned for lack of sufficient evidence of discrimination and alternatively granted a new trial on the damages issue. With respect to the "boy" comments, the magistrate judge concluded with virtually no discussion that "it cannot be found, without more, that they were racial in nature."87

Ash and Tyson appealed this decision to the Eleventh Circuit, which confirmed the district court's view that the "boy" comments alone did not evidence racial animus. ${ }^{88}$ The court stated simply, "While the use of 'boy" when modified by a racial classification like 'black' or 'white' is evidence of discriminatory intent, the use of 'boy' alone is not evidence of discrimination." ${ }^{\circ 9}$ The Supreme Court granted review of this proposition, along with the court's discussion of its standard for establishing pretext.

85. See Ash v. Tyson Foods, Inc., 664 F.3d 883, 887 (11 th Cir. 2011); Ash v. Tyson Foods Inc., No. Civ. A. 96-RRA-3257-M, 2004 WL 5138005, at*1 (N.D. Ala. Mar. 26, 2004); see also Final Order on Rule 50 Motion for Judgment as a Matter of Law, No. Civ. A. 96-RRA-3257-M, 2004 WL 5138005 (N.D. Ala. March 26, 2004).

86. See Ash, $2004 \mathrm{WL} 5138005$, at *1 (stating that the jury awarded each plaintiff $\$ 250,000$ in compensatory damages and $\$ 1,500,000$ in punitive damages).

87. See id. at *6.

88. See Ash v. Tyson Foods, Inc.,,129 F. App'x 529, 533-34 (11th Cir. 2006) (reversing the district court's judgment as matter of law with respect to Hithon, but affirming the judgment as a matter of law with regard to Ash because the trial evidence was insufficient to show pretext and thus insufficient to show unlawful discrimination).

89. Id. at 533 (internal citation omitted). 
In a remarkably short opinion, the Supreme Court concluded that the Eleventh Circuit erred in its treatment of the term "boy" and required that the case be remanded for further consideration. Concluding that it was improper to require a racial modifier in order for the term to be considered racial in nature, the Supreme Court held:

Although it is true the disputed word will not always be evidence of racial animus, it does not follow that the term, standing alone, is always benign. The speaker's meaning may depend on various factors including context, inflection, tone of voice, local custom, and historical usage. Insofar as the Court of Appeals held that modifiers or qualifications are necessary in all instances to render the disputed term probative of bias, the court's decision is erroneous. ${ }^{90}$

Perhaps thinking that this was a simple matter, the above quote is the sum total of the Supreme Court's discussion of the issue. The Court did not discuss the term "boy" or its historical usage by whites as a means of denigrating black men, even though, as a later amicus brief to the Eleventh Circuit showed, there is a long and well-documented history to which it could have referred. ${ }^{91}$ Nor did the Court discuss language in general beyond noting several factors that are relevant to the meaning of a speaker's words: "context, inflection, tone of voice, local custom, and historical usage." 92

That language should be interpreted in context is nothing new, but the Supreme Court did hint at a broader directive than merely the notion that courts must not ignore context. The addition of the terms "local custom" and "historical usage" suggest that the Court had something larger in mind, although it refrained from providing further explanation of these terms or its purpose in including them. The Court implied that it is not just the context of the particular conversation that matters, but that the broader historical context of words and their popular usage should also be considered when determining if a word or words carry biased meaning.

But how should courts do this type of analysis? What type of evidence can a lower court consider to determine the historical context of a word or phrase? And doesn't this type of analysis mean that the speaker's identity is necessarily relevant to this analysis since the historical meaning of a word is often determined in large part by the position and identity of the speaker? Clearly, had the decision maker in Ash been the plaintiff's mother, the use of the term "boy" in reference to him would have carried

90. Ash v. Tyson Foods, Inc., 546 U.S. 454, 456 (2006).

91. See Brief for Civil Rights Leaders Hon. U.W. Clemon et al. as Amici Curiae in Support of Plaintiff-Appellant's Petition for Rehearing En Banc at 7-8, Ash v. Tyson, 664 F.3d 883 (11th Cir. 2011) (No. 08-16135-BB)

92. Ash, 546 U.S. at 456 . 
wholly different meaning. Might it also have carried different meaning had the decision maker himself been African American? These questions were all left unanswered by the Court's one-sentence explanation of its position.

As a result of the Court's unsatisfactory treatment of the issue-and perhaps the Eleventh Circuit's desire to be rid of this case-the circuit court paid virtually no attention to the Supreme Court's direction on remand. Instead, the appellate court, after reviewing the record, concluded again that the usages of the term "boy" by the white decision maker directed at African American employees were "conversational" and "non-racial in context." 93 Once again, that was the sum total of the Eleventh Circuit's discussion of the issue. It, too, failed to consider the historical usage of the term "boy," particularly in the American South, nor did it consider the race of the speaker and the employees at whom the word was directed when deciding that the use was "non-racial." In fact, it is hard to know what the court considered since it saw no need to explain the "context" it was newly reviewing. And why should it? The Supreme Court had provided a list of factors on which the "speaker's meaning may depend," but did not direct the lower courts to consider any specific factor or any particular history in making determinations about the meaning of language in discrimination cases. ${ }^{94}$ The appellate court went on to conclude that neither error pointed out by the Supreme Court altered its holding in the case. ${ }^{95}$

The case might have ended there, with the Eleventh Circuit avoiding a true reconsideration of the issue of language, but for the fact that one plaintiff was still entitled to a new trial on the damages issue. After the 2006 Supreme Court decision and the Eleventh Circuit opinion in response, the case was remanded to the district court for a new trial for plaintiff Hithon. The Circuit did not limit the issues to be considered and, as a result, a full-blown re-trial with new witnesses and new evidence occurred. Perhaps hoping to make something of the Supreme Court's suggestion that there was more to the term "boy" than either the district or appellate courts had allowed, the plaintiff offered additional testimony on the meaning of the word. ${ }^{96}$ At the re-trial, the plaintiff elicited the following testimony from Ash (in support of Hithon's claim of race discrimination) about an incident in which he was called "boy" by the decision maker:

A. False [I]t was break time, it was lunch time. And we were just sitting in the cafeteria having lunch. And Mr. Hatley walks up to the table without

\footnotetext{
93. Ash v. Tyson Foods, Inc., 190 F. App'x 924, 926 (11 th Cir. 2006).

94. Ash, 546 U.S. at 456 .

95. See id. at $926-27$.

96. See id. at 831-33 \& n.5 (finding that the defendant waived his right to call for a mistrial based on the district court's decision to allow additional testimony on the use of the word "boy," pursuant to the Supreme Court's instruction to consider context).
} 
saying anything, but he just said, "Boy, you better get going." So I looked at him. I was shocked that he said it, because, you know, I felt like he said it in a mean and derogatory way.

$* *$

Q. And why was that offensive to you?

A. Because the "boy" word is offensive.

$* * *$

Q. Can you explain to the ladies and gentlemen of the jury why that comment was offensive to you, Mr. Ash?

A. Because, you know, being in the South, and everybody know being in the South, a white man says boy to a black man, that's an offensive word.

Q. What do you equate that to, using the word "boy" to a black man?

A. I equate that to just a racial comment because you might as well use the "N" word if you are going to say that.

Q. He might as well have walked up and said "nigger" to you; right?

A. Yeah. ${ }^{97}$

At the conclusion of the trial, Hithon again won a jury verdict that the Eleventh Circuit would again overturn because of its continued refusal to consider contextual factors. At the second trial, the jury awarded back pay, damages for mental anguish, and punitive damages. ${ }^{98}$ After the retrial, the defendant again filed a Rule 50 motion, but the district court upheld the jury verdict except as to punitive damages. ${ }^{99}$ After Tyson appealed to the Eleventh Circuit, the court once again took issue with the sufficiency of the evidence on discrimination, despite the second jury's verdict in Hithon's favor and the district court's endorsement of it. ${ }^{100}$ Accordingly, the court

97. Id. at 832. Defendant's attorney objected to use of the word nigger by the plaintiff's lawyer and asserted that it was an attempt to infuse an overtly racist term in a case in which that term had not been used. Id. The trial judge sustained the objection finding that it was leading. Id. On appeal, the Eleventh Circuit found the need to express its agreement on this point and to add the following:

We agree. The question was also highly improper because through it counsel for Hithon interjected the emotionally charged " $\mathrm{N}$ " word into the trial, a word that there was no evidence at all that Hatley or anyone else at the plant ever used. This misconduct by Hithon's counsel may explain why the jury returned a verdict in his favor, even though there was insufficient evidence to support it. We need not speculate about that, though, because the judgment is due to be reversed for evidentiary insufficiency anyway.

Id. at $832 \&$ n. 6 .

98. See Hithon v. Tyson Foods, Inc., No. 96-RRA-3257-M, 2008 WL 4921515, at *1 (N.D. Ala. Sept. 30, 2008).

99. Id. at *10.

100. In the interim, the Eleventh Circuit heard another case involving the term "boy" and, while paying lip service to the Supreme Court's guidance on the issue, nevertheless ignored its directive again. See Alexander v. Opelika City Sch., 352 F. App'x 390, 392-93 (11 th Cir. 2009) (affirming a grant of summary judgment on the plaintiff's hostile work environment claim). The plaintiff, a thirty-five-year old African American male working as a custodian in a public high school, claimed he was subjected to numerous instances of white co-workers and his white supervisor calling him "boy." See Alexander v. Opelika City Sch., No. 3:06-CV-0498-WKW, 2008 WL 401353, at*1 (M.D. Ala. Feb. 12, 2008). The district court detailed at least nine instances in which he was called "boy" and in each a white man told 
concluded that the evidence was insufficient to support the jury's verdict and reversed in favor of Tyson. ${ }^{101}$

With respect to the evidence on the decision maker's use of the term "boy," the court refused to change its earlier conclusion. Finding that the law of the case was that the use was non-racial, the court held that it could only change course on this issue if the plaintiff had offered evidence that was "new and substantially different." 102 The more elaborate line of questioning on the meaning of the term "boy" when spoken by a white supervisor to his black subordinate was not, in the court's mind, "new and substantially different" because

[t]he only additional evidence presented at the retrial was Ash's and Hithon's testimony about how and why the use of the term "boy" is offensive to them, but the issue is not what was in their mind when they heard the term but what was in Hatley's mind when he used it, and there was no new evidence about that. ${ }^{103}$

Remarkably, the case did not end there, as the Eleventh Circuit reversed itself in response to a petition for rehearing en banc with the

him to do something, laughed at him while working, cursed at him, or questioned him about disputed timesheets. Id. In the final instance, his supervisor called him "boy" while "talking about "how you tie a noose around somebody's neck." Id. In addition, the plaintiff claimed, without contradiction, that there were many more such instances over the course of two years, although he could remember the specific details of only nine of them. Id. Nonetheless, both the district court and the Eleventh Circuit concluded that these facts were insufficient to rise to the level of "severe or pervasive" enough to constitute a hostile work environment. In assessing the claim, the Eleventh Circuit quoted the Supreme Court's words in Ash v. Tyson, acknowledging that the term "boy" could be probative of racial bias. Id. at *4. But the court still concluded that the claim that he had been called "boy" constantly (although he could recall the specifics of only eight [or nine-there is some inconsistency between the district and appellate courts on this issue]or nine instances in two years) coupled with the fact that none of the comments contained threats of physical violence meant that the alleged conduct was not "severe or pervasive." Compare Alexander, 352 F. App'x at 393, with Williams v. W.G. Johnson \& Son, Inc., No. 1:08-cv-00235-SPM-GRJ, 2010 WL 5583107 (N.D. Fla. Nov. 15, 2010) (use of the term "boy" was evidence of race discrimination because term was used in combination with threat of physical violence).

101. Ash, 392 F. App'x at 833.

102. See id.

103. Id. (emphasis added). This comment is unsettling. Not only did the Eleventh Circuit ignore the Supreme Court's directive about considering historical context and local custom when interpreting the meaning of words in discrimination cases, but it went much further. The standard required by the Eleventh Circuit seems to demand far more than an assessment of the cultural, historical, and contextual meaning of a word-it requires evidence of the speaker's intent in using that word (as if its use alone was not sufficient to demonstrate intent). In fact, the point of including evidence of discriminatory language in many cases is to demonstrate racial animus when it is otherwise denied. Some language, given the proper context, has a dominant meaning that should allow a court to assume that the speaker intended what an objective listener might hear. See D. Wendy Greene, Pretext Without Context, 75 Mo. L. REV. 403, 412 (2010). If adopted by other courts, the Eleventh Circuit's requirement would undermine all evidence of potentially biased language in discrimination cases unless the speaker of those biased words admitted that he or she intended the words to be racist, sexist, or ageist-clearly, a practical impossibility. Once again, the Supreme Court's feeble attempt at direction to lower courts about the treatment of language led to an absurd result at the appellate level. 
support of an amicus brief filed by eleven civil rights leaders, including the Honorable U.W. Clemon, the original trial judge in the case and the first African American federal judge in Alabama. ${ }^{104}$ These distinguished amici contended that the Eleventh Circuit's opinion ignored "the relevant historical and social context" of the term "boy" which, although understood by two juries, seemed to elude the appellate panel. ${ }^{105}$ The civil rights leaders plainly stated:

In a very real sense, the contemporary use of the term "boy" in the workplace, directed at an African American adult male by a white supervisor, is a powerful indication of why our civil rights laws continue to serve a vital function even long after we all hoped that the indignities $A m i c i$ faced would have vanished. ${ }^{106}$

The brief went on to detail the history of the term "boy" when directed at African American men by whites and why, if not a "proxy for 'nigger,' it is at the very least a close cousin." 107 And most importantly, the brief described the contemporary meaning of the term as a racial epithet when directed at African American men by whites, calling this an "accepted social understanding." "108

In response to this resounding denunciation from some of this country's most notable civil rights leaders, the Eleventh Circuit grudgingly changed its mind and finally considered the contextual factors surrounding the term. ${ }^{109}$ On December 16, 2011, the court took the exceptionally rare step of reversing itself in response to the petition. But having already concluded that the evidence presented at the second trial was not "new and

104. Brief for Civil Rights Leaders Hon. U.W. Clemon et al. as Amici Curiae in Support of Plaintiff-Appellant, supra note 91 , at 1 . The other signatories to the brief were: Ms. Dorothy Cotton, the Education Director for the Southern Christian Leadership Conference (SCLC) (1960-68); Rev. Robert S. Graetz, Jr., a leader of the Montgomery Bus Boycott; Dr. Bernard LaFayette, Jr., a leader in the civil rights movement; Rev. Joseph E. Lowery, a founder and former president of the SCLC; Mrs. Amelia Boynton Robinson, Selma civil rights activist; Hon. Solomon Seay, Jr., eminent Alabama civil rights attorney; Rev. Fred L. Shuttlesworth, civil rights pioneer and a founder of SCLC; Rev. C.T. Vivian, Executive Staff for the SCLC; Dr. Wyatt Tee Walker, former Chief of Staff to Dr. King; the Hon. Andrew Young, former Executive Director of the SCLC, Mayor of Atlanta, Congressman, and Ambassador to the United Nations. Id. at 1-2.

105. See id. at 4 .

106. Id.

107. Id. at 5, 8-11 (detailing the use of the term during slavery and segregation to reinforce African Americans' "racially subordinate status" and to "intimidate them and to put them 'in their place' when they threatened the racial order"). Perhaps most poignantly, the brief quoted Dr. King's Letter from Birmingham Jail in which he wrote, '[W]hen your first name becomes 'nigger,' your middle name becomes 'boy' (however old you are) and your last name becomes 'John' ... then you will understand why we find it difficult to wait." $I d$. at 10 (quoting MARTIN LUTHER KING, JR., WHY WE CAN'T WAIT 69 (1964)).

108. Id. at 11-13.

109. See Adam Liptak, Rare but Grudging Judicial About-Face in Bias Case, N.Y. TIMES, Dec. 27,2011 , at A16. 
substantially different" enough to alter the law of the case, on rehearing, the Eleventh Circuit simply stated, "we now reach a different conclusion." 110

At the first trial there was virtually no evidence about the factors relating to the use of the word "boy" that the Supreme Court set forth in the Ash III remand: "context, inflection, tone of voice, local custom, and historical usage." At the second trial, Ash, Ash's wife, and Hithon testified about their perception of Hatley's tone of voice or facial expression when he used the term. Ash testified about his understanding of the word's implications in terms of local custom and historical usage, and Hithon elaborated on that subject as compared to his testimony in the first trial. ${ }^{111}$

This "new" evidence led the appellate court (in its fourth look at the case) to finally conclude that there was enough evidence for a reasonable jury to have found that Tyson discriminated against the plaintiff on the basis of his race. Reflecting a remarkable unwillingness to admit its mistake fully, the court concluded that "[ $t]$ he verdict could have gone either way, and it went Hithon's way." 112 Nonetheless, the court reversed itself, finally willing to take a realistic look at the way in which language is used in our culture.

Why did it take seven years and a scathing amicus brief from America's civil rights leaders to reach a realistic and just result in $A s h$ ? A similar question could be asked in Burlington. Why, despite widespread recognition that the word "nigger" has substantially different meanings in contemporary culture based on the context and racial identity of the speaker, does the view persist that discrimination law precludes contextdriven consideration of language? There is a somewhat inexplicable, widening gap between the use and meaning of words in American culture and courts' treatment of those words. And, as the following section demonstrates, despite the Supreme Court's 2006 guidance to consider "local custom" and "historical usage," the problem persists.

\section{B. The Treatment of Discriminatory Language by Other District and Appellate Courts}

The problem is not unique to the $A s h$ case. In fact, since the Supreme Court's opinion in $A s h$, both appellate and district courts around the country have often mistreated language in discrimination cases. The cases tend to

110. Ash v. Tyson Foods, Inc., 664 F.3d 883, 897 (1 1 th Cir. 2011).

111. Id. (quoting Ash v. Tyson Foods, Inc., 546 U.S. 454, 456 (2006)). The court also noted that "the evidence about the timing of the comment to Ash was also different at the second trial. At the first trial Ash and his wife testified that the comment in the cafeteria was made sometime after the promotion decisions at issue in this case, but at the second trial they testified that the comment was made just before the promotion decisions." Id.

112. Id. at 898 . 
fall into one of two categories: (1) those cases that, like Ash and Burlington, refuse to consider the context-driven meanings of words, or pay only lip service to their cultural and historical meaning, while undermining that reality in the cases' ultimate conclusions; ${ }^{113}$ and (2) those cases that do consider cultural meaning and the importance of the identity of the speaker to that meaning, but fail to make explicit this consideration. ${ }^{114}$

In the first category of cases, courts tend to be faced with words or phrases that are not obviously racial in nature. But in each instance, the plaintiff expresses deep offense to the words used and views them as decidedly racist. As with the term "boy" in $A s h$, courts often seem out of step with American culture and modern linguistic realities. For example, in a recent case out of the Sixth Circuit, the court considered the phrase "you people" and whether it had racist meaning. ${ }^{115}$ The plaintiff brought a claim of race-based discrimination related to his paid work assignment while he was incarcerated in a Michigan correctional facility. According to the plaintiff, after an investigation found him "not guilty" of misconduct, he was terminated from his position anyway after being issued a negative work evaluation. After learning that he would be terminated, the plaintiff ran into two supervisors, one African American and one white. The African American supervisor stated, "Ya'll some worthless convicts. Some niggers that are insignificant in the scheme of things around here."116 When the plaintiff asked why he was being fired, the white supervisor, referencing the African American supervisor who had held the hearing at which the plaintiff was found not guilty, responded: "And we know about ... Wade. And we know how you people stick together." 17 The plaintiff alleged that

113. The problem is not limited to racial terms. While the term "girl" was, in the past, an acceptable word even when directed at a woman, that is no longer the case in contemporary culture. If a male supervisor uses the term "girl" about his female subordinate, it should certainly be an indication that he may harbor sexist tendencies. But its use by women carries an entirely different meaning that may conjure camaraderie or other emotions rather than bias. Nonetheless, courts have failed to acknowledge this reality. See, e.g., Creech v. Ohio Cas. Ins. Co., 944 F. Supp. 1347, 1358 (S.D. Ohio 1996) ("The Court first concludes that Manring's use of the words 'girl' and 'gal' to refer to female employees does not constitute direct evidence of discrimination. Those terms are ambiguous at best and do not reveal any hostility or animus toward women. Indeed, as Defendant has observed, Plaintiffs themselves repeatedly used the term 'girl' to refer to other adult females during their depositions.").

114. See, e.g., Slocum v. Guardsmark, L.L.C., No. 08-685, 2009 WL 3448126, at *4-5 (E.D. La. Oct. 22, 2009).

115. Umani v. Michigan Dept. of Corr., 432 F. App'x 453, 458 (6th Cir. 2011) (analyzing equal protection violations under both a direct evidence of discrimination analysis and the McDonnell Douglas burden-shifting framework).

116. Id. at 456 .

117. Id. 
it was these two supervisors who were responsible for changing a good work evaluation to a far-below average evaluation. ${ }^{118}$

The court considered these statements in its analysis of direct evidence of discrimination and held that they did not evidence racial discrimination. Rejecting the interpretation of the magistrate judge on summary judgment, the appellate court concluded that the phrase "you people stick together" was not necessarily a reference to the black supervisor favoring members of his own race. Instead, the court concluded that such an explanation was but one possible interpretation of this "ambiguous comment" and that the white supervisor's "use of the term 'you people' does not qualify as a clear reference to race" and might instead be a general reference to the prisoners and staff on the plaintiff's cell block. ${ }^{119}$ Like the original Eleventh Circuit opinion in $A s h$, the Sixth Circuit stated that "[w]ithout other allegations indicating a racist meaning, this ambiguous comment is not in and of itself racist." 120

In reaching this conclusion, the court did not consider popular culture references, current dictionaries, or even the testimony of the plaintiff. Instead, the Sixth Circuit cited two district court cases that had also addressed the phrase "you people" and its potentially racist meaning. The first case cited, from an Ohio court, involved a section 1981 claim against a restaurant that had refused to serve a group of young African American males. $^{121}$ In turning the group away, the plaintiffs alleged that the manager had referred to them as "you people." "122 Like the Sixth Circuit, this case devoted a few short sentences to its consideration of the phrase: "[T]he term 'you people' is commonly used in many contexts and, while offensive to some regardless of their race, cannot be said to specifically refer to race. Other courts have reached this same conclusion that the use of the term

118. See id. at $456-57$

119. Id. at 459 .

120. See id. at 459-60 (quoting NLRB v. Foundry Div. of Alcon Indus., 260 F.3d 631, 635 (6th Cir. 2001). Ironically, the court also commented that "the word 'niggers' is a racial slur 'irrespective of its common usage and without regard for the race of those who use it." $I d$. (quoting NLRB v. Foundry Div. of Alon Indus., 260 F.3d 631, 635 (6th Cir. 2001)). Notably, in this case, the term "nigger" was spoken by an African American man and directed at an African American subordinate. And yet, despite the court's pronouncement that the term is always a racial slur, the court did not consider evidence of its usage as direct evidence of discrimination because it concluded that the speaker of the term was not the decision maker and that there was insufficient evidence that his evaluation influenced the decision maker. These courts' comments together demonstrate how out of step courts are with modern culture in which it is common knowledge that the phrase "you people" when directed at African Americans is rarely anything but a racist statement, while the term "nigger" can have numerous meanings depending on the identity of the speaker.

121. See Scott v. Thomas \& King, Inc., No. 3:09-CV-147, 2010 WL 2630166, at *7 (S.D. Ohio June 28, 2010).

122. See id. 
'you people' is not direct evidence of race discrimination." 123 And like the Sixth Circuit, the Ohio court cited another case as support for its conclusion about the meaning of the phrase. ${ }^{124}$

The second case cited by the Sixth Circuit, from a Michigan court, involved a prisoner's civil rights claim that he and other African American prisoners were treated poorly in their work assignments as a result of their race. When the plaintiff complained to his white supervisor about the perceived discrimination, the supervisor responded, "You people don't do what I do, stay in your place Wilson."125 Here again, the court's opinion demonstrated virtually no consideration of the meaning of this phrase and merely held that the statement "does not in itself clearly constitute a racial statement."126 This is particularly troubling given the context of the statement, namely that the supervisor was responding to an allegation of race discrimination when he used the phrase "you people."127

While these courts seem convinced, with virtually no discussion, of the neutrality of the phrase "you people," a simple internet search shows that in popular culture, the words have a definite racial connotation when directed at a group of African Americans by someone who is not black. ${ }^{128}$ For example, former presidential candidate Ross Perot offended a black audience when he used the phrase in an appearance before the NAACP's 1992 national convention in Nashville, Tennessee. ${ }^{129}$ Perhaps unlike "boy," the phrase "you people" is not necessarily racist. However, when used by a member of an "out -group" and directed at a group of people who all belong

123. Id. at *9.

124. Id. at *7 (citing Amold v. Marous Bros. Constr. Inc., No. 1:03 CV 1761, 2005 U.S. Dist. LEXIS 44017, at*10 (N.D. Ohio Feb. 3, 2005), aff'd 211 F. App'x 377 (6th Cir. 2006); Nguyen v. City of Cleveland, 229 F.3d 559, 563 (6th Cir.2000)).

125. Wilson v. Buschell, No. 2:05-cv-106, 2007 WL 2780886, at *1 (W.D. Mich. Sept. 20, 2007).

126. See id. at *3.

127. See $i d$. at *1.

128. See, e.g., Diane Cardwell, Transit Strike: Subtext; Race Bubbles to the Surface in Standoff, N.Y. TIMES, Dec. 22, 2005, http://www.nytimes.com/2005/12/22/nyregion/nyregionspecial3/ 22race.html (giving examples of how the public response to an MTA strike had racist undertones, including when commentators called the mostly black, Latino, and Asian-American workforce "you people"); URBANDICTIONARY.COM (defining "you people" as both non-racial and as a phrase that "has become known as a racial epithet targeted to blacks"), http:/www.urbandictionary.com/ define.php?term=You\%20People (last visited Nov. 7, 2012).

129. See Peter Appelbome, THE 1992 CAMPAIGN: Racial Politics; Perot Speech Gets Cool Reception at N.A.A.C.P., N.Y. TIMES, July 12, 1992, http:/www.nytimes.com/1992/07/12/us/the-1992campaign-racial-politics-perot-speech-gets-cool-reception-at-naacp.html?pagewanted $=$ all \&src $=\mathrm{pm}$ (statement of Willie Clark, president of the San Bernadino, California branch of the NAACP) ("When [Ross Perot] said 'you people' or 'your people,' it was like waving a red flag in front of a bull. ... It's something white folks have used when they don't want to call you nigger, but they don't want to treat you like an equal.") (internal quotations removed); John M. Broder, NAACP Offers Chilly Response to Perot Speech, L.A. Times, July 12, 1992, http://articles.latimes.com/1992-07-12/news/mn-4266_1_rossperot. 
to a specific race, religion, ethnicity, or sex, the phrase is decidedly derogatory. ${ }^{130}$ For example, when used by gentiles and directed at a group of Jews, the phrase typically carries an anti-Semitic meaning. When used by heterosexuals and directed at a homosexual audience, the phrase most likely expresses homophobia. While courts seem to think that a racial or other modifier is required to determine the phrase's biased meaning, it is actually the context and the identity of the speaker and listeners that matters. ${ }^{131}$ This is exactly what the Supreme Court seemed to suggest in its Ash opinion, but failed to convey that message effectively.

The second category of cases which mistreat discriminatory language includes courts that do implicitly understand the role of context and the racial (or other) identity of the speaker and listeners in assessing language in discrimination claims. However, the courts in this category nonetheless fail to make their consideration of these factors explicit, thereby doing a disservice to the development of the law. As a general matter, these courts typically assess allegedly discriminatory language used in the workplace in light of the identity of the actors, but fail to admit that context and culturally important cues guide the conclusions they reach.

For example, the Fourth Circuit engaged in inexplicit context-driven analysis when it decided a case in 2010 involving claims of racial and sexual harassment brought by an African American female police academy recruit. ${ }^{132}$ The plaintiff made several allegations about language used by both recruits and instructors. The plaintiff was the only woman and African American in an otherwise entirely male and, with the exception of one biracial (part African American) recruit, entirely white class of recruits. ${ }^{133}$

130. In fact, Ann Romney recently learned that the phrase "you people" in any context creates a whirlwind of negative attention. As New York Magazine pointed out, "As a rule of thumb, 'you people' is not a very nice way to address a group of people. Sometimes, it comes off as racist. Or it can seem scornful and condescending when the utterer is, say, extraordinarily wealthy and 'you people' refers to the American public. So when Ann Romney told Good Morning America today that she and her husband had released 'all you people need to know and understand about our financial situation,' it was the verbal equivalent of watching her trample a homeless man on her dressage horse, and predictably, the quote went viral." Dan Amira, We Don't Think Ann Romney Said 'You People', NEW YoRK MAGAZINE, July 19, 2012, http://nymag.com/daily/intel/2012/07/ann-romney-you-people-taxesvideo.html. As Amira notes, the particular derogatory meaning of the phrase depends wholly on the identity of the speaker, who, in Romney's case, is an extremely wealthy person whom some consider out of touch with the rest of the American people.

131. This Article does not suggest that any of the "you people" cases it discusses should have come out differently - to make such a call would require consideration of all of the evidence available to the court. Rather, it is concerned with the flippant nature of courts' considerations of the phrase, the failure to take into account contextual factors when interpreting its meaning, and the seeming belief that there is an objective definition for words and phrases so that other cases with entirely different facts and contextual factors can be looked to for such definitions.

132. See Mosby-Grant v. City of Hagerstown, 630 F.3d 326, 326 (4th Cir. 2010).

133. See id. at 329. 
In support of her claim of a racially hostile work environment, the plaintiff pointed to several racially charged comments. First, she claimed to have overheard a white male recruit telling the biracial recruit that "where I'm from, people like you are strung up from a flagpole" and commenting about the biracial recruit being "dragged from the back of a truck." 134 When she confronted the white male recruit who made these comments, he apologized and told the plaintiff that he and the biracial recruit had been joking. ${ }^{135}$ In addition to these comments, the plaintiff noted that she had heard the recruits use the terms "honky" and "cracker" and, in one instance, heard a recruit refer to Britney Spears as "white trash" and "ghetto."136 In support of her sexually hostile work environment claim, the plaintiff alleged that recruits and, on at least one occasion, an instructor used the word "bitch."137 In addition, between classes, recruits often sang a song that included the phrase, "asses, titties and big booty bitches" and often made crude comments about the physical appearance or anatomies of women who visited or passed by the police academy. ${ }^{138}$

The Fourth Circuit considered the alleged comments and conduct in reviewing the plaintiff's claims and concluded that the plaintiff's race discrimination claim must fail while her sexual harassment claim should go forward. In assessing her race discrimination claim, the court mentioned the comments about lynching and being dragged from a truck, but was careful to note that the speaker immediately apologized and that he had been talking to a biracial man with whom he had been "joking."139 The court viewed these overtly derogatory comments as somehow neutralized by the presence of a biracial listener who was willing to engage in the "joke."

What is most interesting about the court's approach in this case, however, is not what it said, but rather, what it failed to say. The court did not make any mention of the recruits' use of the terms "honky," "cracker," or "white trash" as evidence of racial bias. Many readers will understand that these terms were not included in the analysis because they are derogatory terms for white people and used by white people, thereby negating or, at the very least, minimizing their derogatory nature. When

134. Id. The comment about being "dragged from a truck" was, the court explained, a reference to the brutal and well-known murder of James Byrd, a forty-nine-year old African American man who was beaten by three white men who then chained him to the back of a pickup truck and dragged him down the street. Id. at 335 n.3.

135. See id. at 329.

136. Id. at 330 .

137. See id.

138. See id. at 330-31.

139. See id. at 336. 
white people use these terms about themselves, it is an "in group" use of a slur as an acceptable joke. Had these terms been used by African American recruits and directed at whites, they likely would have carried a far different meaning. Here, the use by whites evinced a joke rather than evidence of race discrimination, thus negating the need to consider those terms in its analysis of the discrimination claim. But the court said none of these things. It discussed the context of the lynching comments without opining on its relevance and simply left out any mention of the white slurs in its analysis. In so doing, the court implicitly considered the impact of contextual factors on language but failed to make its analysis explicit.

The Fourth Circuit's approach to the sex discrimination claim similarly suggests that the court informed its interpretation of the remarks from the surrounding context. In finding for the plaintiff on her sex-based hostile work environment claim, the court focused on the fact that "sexist comments were pervasive" at the all-male academy. ${ }^{140}$ "The dozens of references to women as "bitches," "crazy," and "prostitutes" were extremely important to the court. But the court failed to mention, when assessing the import of these words, the gender identity of those who used them. In each instance, a male recruit or instructor used these terms in reference to a woman. This almost certainly affected the court's consideration of the role these words played in the workplace. Had the plaintiff alleged that her female co-workers called each other "bitches" or "hoes" in a playful manner, the court would likely have been far less impressed with such words as "sexist comments" and would likely have considered them "jokes" like the racist comments made to the biracial recruit. Nonetheless, the court failed to mention the role that the identity of the speaker played in its assessment of the terminology used.

Here, then, is an example of a court considering language in its proper context for both race discrimination and sexual harassment claims by taking into account in each instance the identity of the speaker and listener, but at the same time failing to make explicit its consideration of context or, possibly, even failing to recognize that the consideration of context colored its own conclusions. While this Fourth Circuit opinion could have been instructive on this issue for lower courts, it was instead another missed opportunity to acknowledge and explain the cultural, historical, and contextual factors that impact the meaning of language.

This same subconscious consideration of context plays out constantly throughout the country in cases involving the term "nigger." Unfortunately, the term has a somewhat ubiquitous presence in employment discrimination suits. It appears with regularity in both hostile work environment cases, as 
the basis for the discrimination itself, as well as in disparate treatment cases, as evidence of the decision maker's bias meant to rebut any legitimate nondiscriminatory reason that the defendant may offer. For example, in three separate cases from district courts in Louisiana, Texas, and Tennessee, the plaintiffs' hostile work environment claims were based in large part on the use of the term, whether or not it was directed at the plaintiff. ${ }^{141}$ In each of these cases, the court described the comments by first noting the race of the speaker as white or Caucasian and the race (in these cases, African American) of the listener as well. ${ }^{142}$ That a white person directed the term at an African American person gave the courts pause. ${ }^{143}$ But in each case, despite identifying the race of the speaker, the courts failed to explicitly acknowledge that they were using race in their considerations of the racially discriminatory language. This failure should not be overlooked. By failing to acknowledge the import of this contextual factor, these courts are implicitly suggesting that they are not permitted to consider it. Why else would they leave out such an important point? It is possible that the context-driven meaning of slurs is so ingrained in the cultural lexicon that some judges actually fail to realize that they are taking race into account when interpreting such language. More likely, however, the courts' failure to discuss the race of the speaker indicates a belief, expressed in the Burlington case, that Title VII does not condone courts' consideration of race because of the statute's language expressly forbidding such consideration in the employment context. As I will discuss supra, such a reading of Title VII is overly literal and not in keeping with treatment of the statute in other contexts.

The Burlington case, while the flipside of most typical discrimination cases, raises the same problems of language interpretation and, in fact, highlights those problems. In the typical race discrimination case, an African American plaintiff claims that racially charged language was used against him or her, and the court responds by refusing explicitly to consider the identity of the speaker of that language when analyzing its import, or by doing so only implicitly. By contrast, the Burlington plaintiff was white and himself used the slur, but the court faced the same dilemma-whether consideration of the speaker's identity would itself run afoul of antidiscrimination law. Unlike the typical case, however, Burlington brought the issue squarely to the forefront because it was not only the

141. See Slocum v. Guardsmark, L.L.C., No. 08-685, 2009 WL 3448126, at *2 (E.D. La. Oct. 22 , 2009); Cooper v. Wal-Mart Transp., L.L.C., 662 F. Supp. 2d 757, 782-83 (S.D. Tex. 2009); Goree v. United Parcel Service, Inc., No. 05-2393 B/V, 2008 WL 276482, at*1 (W.D. Tenn. Jan. 30, 2008).

142. See Slocum, 2009 WL 3448126, at *4; Cooper, 662 F. Supp. 2d at 765; Goree, 2008 WL 276482 , at $* 1$.

143. See, e.g., id. at *5 (commenting that "this term ['nigger'] is surely highly objectionable"). 
court's consideration of race that mattered but the employer's consideration as well. Because Burlington turned on whether the use of the term "nigger" by a white person could be punished differently than it would be if the speaker were black, the court felt compelled to address the question head on. And the existing precedents, including the Supreme Court's rather unhelpful language in $A s h$, made it nearly impossible for the trial court to approach the question with any creativity. Language is undoubtedly impacted by contextual factors-social and historical realities and the identity of the speaker among them. In fact, that identity can wholly change the meaning and import of a word. Nonetheless, the Burlington court had nowhere to turn in support of such a proposition and instead looked only to the literal words of Title VII.

\section{Misinterpretation of Language as a Result of an Overly Narrow Approach to Discrimination Cases Generally}

If the linguistic meaning as context driven is both a matter of popular consensus, and a matter of agreement among many linguists, anthropologists, and legal scholars, why then does it seem to continually elude courts in discrimination cases? Courts' myopic approach to language may result from a more widespread problem in employment discrimination cases Sandra Sperino recently considered in her article Rethinking Discrimination Law. ${ }^{144}$ Sperino argues that as a result of the rubrics and frameworks imposed by the Supreme Court in this area, including the McDonnell Douglas burden-shifting framework, "discrimination analysis has been reduced to a rote sorting process" and that "this practice creates an unduly limited lens through which to view discrimination."145 It is possible that courts' approach to discriminatory language in employment cases follows from the formalistic way in which courts are conditioned to consider these cases in general.

Because the rubrics used in employment discrimination cases have created such powerful formulas and structures for approaching discrimination, courts have been trained to abandon instinct and a realistic view of the world in favor of multifactor tests. ${ }^{146}$ If courts generally

144. Sandra Sperino, Rethinking Discrimination Law, 110 MICH. L. REV. 69 (2011).

145. Id. at 71,94 .

146. The misinterpretation of discriminatory language may even stem from a far larger movement in which Enlightenment concepts of intellectual and social separation have been incorporated into common law processes favoring "formal equality and the social image of atomized, strongly choosing individuals" despite significant changes in Post-Enlightenment culture, which acknowledge differences between people and the "relational contexts to which people often consider themselves bound." Thomas D. Barton, Troublesome Connections: The Law and Post-Enlightenment Culture, 47 EMORY L.J. 163, 165 (1998). This, in turn, has led to the realization that traditional legal methods are "impractical" or lead to ironic or absurd results. Id; see also id. at 172-175, 184-187 (describing Enlightenment concepts 
disfavor an experience-based or "realistic" approach to the world, the treatment of language surely suffers the same fate. Instead of interpreting words and phrases in light of the context of the situation, the identity of the speaker, and the cultural and historical realities that inform linguistic meaning, courts tend to seek the import of words in other cases and essentially divorce the reality of the situation from the word's meaning. ${ }^{147}$

The extension of these frameworks to a formalistic approach to language in discrimination cases leads to poor outcomes. These overly formalistic rubrics force courts to view every problem through the same tired lens. This, in turn, directs courts to reference only one another in filling out the required elements of a case, rather than looking to the extralegal world's conceptions of the definition and experience of bias. These rubrics also force courts away from the macro consideration of the intent behind antidiscrimination law and focus them instead on the micro issues raised by the rubrics. The result is an utter failure in the law to conceive of language the way the rest of the world does and to mistreat the language of discrimination to the point of absurdity.

Despite this failure by trial courts and appellate courts alike, a more honest approach to language would be both tolerable under Title VII and other antidiscrimination statutes and, in fact, consonant with the overall goals of those laws-and Title VII, in particular. As the next section clarifies, there is ample precedent for non-literal interpretations of Title VII that would, in turn, allow for identity-conscious considerations by employers and courts.

\section{Endorsing a Flexible Reading of Antidiscrimination Statutes that Supports Their Essential Purpose}

Rather than hewing to the strict text of Title VII and other antidiscrimination statutes, the Supreme Court and lower courts have endorsed flexible readings of those statutes that support their original purposes. As a result, it is incorrect to reject an identity-conscious consideration of language on the basis that it would technically run afoul of the statutory text, when a context-driven approach to language would effectuate the purposes of the statute at issue.

The original purpose of Title VII, as part of the Civil Rights Act of 1964, was to eradicate discrimination against African Americans and other

\footnotetext{
of separation including the privileging of the actor's perspective over that of the victim and the idea of "segmentation" by "isolating issues in the material world from their historical and social context").

147. See D. Wendy Greene, Pretext Without Context, 75 Mo. L. REV. 403, 416 (2010) (arguing that in analyzing cases under the McDonnell Douglas framework, courts are "inserting race-neutral, acontextual inferences that justify a finding of lawful behavior and dismissal of discrimination claims.").
} 
minorities in the workplace. ${ }^{148}$ The House Judiciary Committee itself commented on the reasons for enacting Title VII:

The United States is a nation of many people. The interests of some are not always the interests of all. In sustaining our way of life and in preserving our historic traditions, however, the fundamental rights of each citizen must be protected. And, in order for our Nation to maintain its role as world leader, the hopes and aspirations of minorities must always be safeguarded....

Every segment of American life must bear a heavy burden in this epochal struggle. ${ }^{149}$

While it is undoubtedly true that the Supreme Court has, under Title VII, endorsed protection of whites and other majorities against discrimination, ${ }^{150}$ the original purpose of Title VII is clear-protection and advancement of minorities.

But how should courts incorporate this understanding of the law into their interpretations of discriminatory language? And what is the response to courts that look to the literal language of the statutes and consider themselves bound by those exact words? The Court's early jurisprudence on affirmative action is instructive on these questions. ${ }^{151}$ In its initial comments on voluntary affirmative action plans, the Court counseled against a "literal interpretation of Title VII" and held that the statute must be read in keeping with its legislative history and historical context. ${ }^{152}$ As

148. See, e.g., H.R. Rep. No. 88-914, at 18 (1963), reprinted in 1964 U.S.C.C.A.N. 2391, 2393 (acknowledging that although there is discrimination against minority groups in general, discrimination against blacks is the "most glaring" and that "[i]n the last decade, it has become increasingly clear that progress has been too slow and that national legislation is required to meet a national need which has become ever more obvious"); United Steelworkers v. Weber, 443 U.S. 193, 202 (1979) (stating that the purpose of Title VII was not to respond to discrimination against white people but to deal with "the plight of the Negro in our economy").

149. H.R. Rep. No 88-914, supra note 145 , at 32.

150. See McDonald v. Santa Fe Rail Transp. Co., 427 U.S. 273, 280 (1976).

151. In looking to these early affirmative action cases, this Article is cognizant of the Court's changing approach to affirmative action and discrimination in general. While the Court that decided Weber and Johnson had a flexible view that allowed for race-conscious decision making, the Roberts Court appears to be heading in the other direction. See Parents Involved in Cmty Sch. v. Seattle Sch. Dist. No. 1, 551 U.S. 701, 748 (2007) (approving of a colorblind approach, stating, "[t]he way to stop discrimination on the basis of race is to stop discriminating on the basis of race"). In addition, as Bradley Areheart argues, anti-discrimination law in general may be emphasizing anti-classification principles rather than the original anti-subordination principles that spurred the law. See Bradley Areheart, The Anticlassification Turn in Employment Discrimination Law, 63 ALA. L. REV. 955 (2012). Nonetheless, the early affirmative action precedents and the anti-subordination principles behind them still stand, still guide much of anti-discrimination law, and are applicable in the linguistic interpretation context as well.

152. See Weber, 443 U.S. at 201 ("The prohibition against racial discrimination in $\$ \S 703(a)$ and (d) of Title VII must therefore be read against the background of the legislative history of Title VII and the historical context from which the Act arose."). 
the Court noted, it is a "familiar rule that a thing may be within the letter of the statute and yet not within the statute, because not within its spirit nor within the intention of its makers." 153 Accordingly, in endorsing voluntary affirmative action plans that contain racial preferences as permissible under Title VII, the Court made clear that "an interpretation of [Title VII] that forbade all race-conscious affirmative action would bring about an end completely at variance with the purposes of the statute and must be rejected."154

The notion that Title VII's words must be interpreted flexibly to effectuate the statute's purpose guided both Justices Stevens and O'Connor in their concurrences in Johnson v. Transportation Agency. ${ }^{155}$ Justice Stevens stated clearly that " $[\mathrm{t}]$ he logic of antidiscrimination legislation requires that judicial constructions of Title VII leave 'breathing room' for employer initiatives to benefit members of minority groups."156 Justice O'Connor made the point even more clearly, noting that "[section] 703 has been interpreted by Weber and succeeding cases to permit what its language read literally would prohibit."157 As these passages and the affirmative action cases in general demonstrate, the purpose of Title VII sometimes trumps its literal words. In essence, the Court recognized that there are competing evils at play in affirmative action cases-potential unfairness to whites and other members of majority groups when minorities receive preferential treatment and, on the other side, historical discrimination against minorities that creates intolerable disadvantages for an entire segment of the population. ${ }^{158}$ In the face of this reality, the Court has chosen to permit preferential treatment of minorities because that conclusion comports with the essential goals of antidiscrimination laws, if not always with their literal words. ${ }^{159}$

153. Id. at 201 (citing Holy Trinity Church v. United States, 143 U.S. 457, 459 (1892)).

154. Id. at 202 (internal quotations marks omitted).

155. See Johnson v. Transp. Agency, 480 U.S. 616, 645 (1987) (Stevens, J., concurring); id. at 647 (O'Connor, J., concurring).

156. Id. at 645 (Stevens, J., concurring).

157. Id. at 647 (1987) (O'Connor, J, concurring).

158. See id. at 630-38. This notion of allowing the purposes of antidiscrimination law to guide courts when faced with competing evils arose also in Ricci v. DeStefano, 557 U.S. 557, 580 (2009) ("We consider, therefore, whether the purpose to avoid disparate-impact liability excuses what otherwise would be prohibited disparate-treatment discrimination. Courts often confront cases in which statutes and principles point in different directions.... [O]ur decision must be consistent with the important purpose of Title VII-that the workplace be an environment free of discrimination, where race is not a barrier to opportunity.").

159. See Weber, 443 U.S. at 204 ("It would be ironic indeed if a law triggered by a Nation's concern over centuries of racial injustice and intended to improve the lot of those who had been excluded from the American dream for so long, constituted the first legislative prohibition of all 
Analogizing this to the interpretation of language, it is clear that flexibility in statutory interpretation is required. What does this mean in practice? Given that the purposes of Title VII and other antidiscrimination laws are to protect minorities from discriminatory treatment in the workplace, and given that the Supreme Court has explicitly endorsed a nonliteral reading of Title VII in order to accomplish this goal, it is appropriate for both courts and employers to consider all contextual factors in interpreting discriminatory language, including the racial (or other) identity of the speaker of such words, because doing so similarly effectuates the purposes of these statutes. ${ }^{160}$ Although such consideration may run afoul of the literal words of Title VII (that employers may not "discriminate against any individual with respect to his compensation, terms, conditions, or privileges of employment, because of such individual's race, color, religion, sex, or national origin"|61), identity-conscious decision making is appropriate in this context. This is because it is impossible to consider the realities of modern language and simultaneously adhere strictly to the words of Title VII. In deciding how to proceed, courts should use the purposes of antidiscrimination law as a guide.

While robust guidance from the Supreme Court has been lacking and may go a long way towards encouraging context-conscious interpretation of language, additional solutions are required to ensure a more honest and realistic treatment of language at the trial court level. Part IV of this Article will explore solutions to this problem-sources to which courts can turn to

voluntary, private, race-conscious efforts to abolish traditional patterns of racial segregation and hierarchy.") (internal quotation marks omitted).

160. The Supreme Court has begun this process in sexual harassment cases in which it has implicitly made consideration of sexual orientation of a perpetrator relevant to a determination of actionable sexual harassment. In Oncale v. Sundowner Offshore Services, Inc., 523 U.S. 75 (1998), the court, in concluding that same-sex sexual harassment is actionable, focused on the relevance of contextual factors to the demonstration of discriminatory conduct. The court noted:

In same-sex (as in all) harassment cases, [the] inquiry requires careful consideration of the social context in which particular behavior occurs and is experienced by its target ... The real social impact of workplace behavior often depends on a constellation of surrounding circumstances, expectations, and relationships which are not fully captured by a simple recitation of the words used or the physical acts performed. Common sense, and an appropriate sensitivity to social context, will enable courts and juries to distinguish between simple teasing or roughhousing among members of the same sex, and conduct which a reasonable person in the plaintiff's position would find severely hostile or abusive.

Id. at 81-82 (emphasis added).

This is the type of guidance needed for all discriminatory language cases instead of only in same-sex hostile work environment cases, but courts tend to ignore it when dealing with other types of discriminatory conduct. But see Passananti v. Cook Cnty., 689 F.3d 655, 665 (7th Cir. 2012) (focusing on context of word use to determine if supervisor's use of "bitch" was "because of sex" and thus evidence of sexual harassment but omitting any discussion of the supervisor's maleness-his gender identity - as a contextual factor).

161. 42 U.S.C.A. $\$ 2000 \mathrm{e}-2$ (a)(1) (West 2012). 
infuse their interpretation of discriminatory language with a more intellectually honest and context-driven approach.

IV.

Possible SOLUTIONS TO THE PROBLEM OF MisinTERPRETATION OF

\section{DISCRIMINATORY LANGUAGE}

There is no easy fix to what appear to be ingrained patterns of mistreatment of language in discrimination cases. The solution this Article offers is perhaps only the tip of the iceberg, and a more global solution involving, as Sperino recommends, a wholesale reevaluation of the rubrics of employment discrimination law may ultimately be required. In the interim, this Article proposes how to begin to reshape courts' (and, by extension, employers') treatment of the language of discrimination.

\section{A. Incorporating Expert Evidence to Insure Consideration of Linguistic Realities}

Expert testimony should be allowed-and even encouraged-in cases involving discriminatory language. Rather than looking to other courts to determine the meaning of a particular word or phrase, courts should be open to hearing the opinions of linguists, anthropologists, sociologists, and psychologists who spend their careers researching the development and meaning of language and its relationship to the culture in which it is used.

The cases examining the words "boy" and "you people" demonstrate the pressing need for such expert intervention. In each of these cases, the courts felt the need to include an explanation of the meaning of the term or phrase, but looked to rather unreliable sources to provide the definitionother courts that had examined the phrase in entirely different contexts. This practice creates several problems.

First, courts are in no position to opine on the meaning of language in culture and instead, are far better positioned to articulate legal rules and theories and to apply those rules to a set of facts. When faced with the meaning of words in contracts or statutes, courts typically look to the document itself for a definition or, at most, to an accepted dictionary that will provide an "objective" meaning. ${ }^{162}$ It is absurd to think that courts can effectively move from this type of objective search to one in which they determine the cultural meaning of racially charged (or other discriminatory) language which, by its nature, is both subjective and fluid.

162. See Saint Francis Coll. v. Al-Khazraji, 481 U.S. 604, 610-11 (1987) (citing nineteenthcentury dictionaries to define "race" in 42 U.S.C. $\S 1981$ ). 
Second, the fluidity of language itself makes the practice of looking to other cases for word meaning an impossibly futile strategy. Such a search instead locks in the meaning of a word or phrase based on the context of the case in which it first appeared. All future discussions of the word's meaning become entirely self-referential. This process is both antithetical to the concept of a developing language and ignores the Supreme Court's instruction in $A s h$ to consider the "context, inflection, tone of voice, local custom, and historical usage." 163

Instead of looking to other courts, expert evidence should be relied upon at the summary judgment phase and, if necessary, should be admitted at trial. At summary judgment, an obstacle faced by the large majority of employment discrimination plaintiffs, ${ }^{164}$ litigants should be permitted (and even encouraged) to rely on depositions of expert witnesses who can serve as quasi-translators for courts. These witnesses may discuss the ways in which language changes based on the historical and cultural context in which it is used and, indeed, by the identity of the speaker and listeners. Experts should be permitted to discuss the development of language in general and, based on their expert knowledge, to opine on the meaning of a word or phrase in the context in which it arises in a specific case. A legitimate dispute as to the meaning of a word in a given context that is material to the disposition of the case would be an appropriate basis on which to deny summary judgment and move to trial, no different than other disputes of material facts. ${ }^{165}$

At trial, expert testimony may also be extremely helpful to jurors, who might otherwise be tempted to apply only their own life experiences, however relevant, to the question of word meaning. For example, it is not difficult to see how an all-white jury might benefit from expert testimony on the historical meaning of the term "boy" when used by a white superior and directed at an African American male who was his subordinate in a workplace. The fact that the allowance of such expert testimony may result in a "battle of the experts" is no reason to disallow such evidence. The

163. Ash v. Tyson, 546 U.S. 454, 456 (2006).

164. See Elizabeth M. Schneider, The Changing Shape of Federal Civil Pretrial Practice, $158 \mathrm{U}$. PA. L. REV. 517, 548-49 (2010) ("Longitudinal studies conducted by the Federal Judicial Center on summary judgment show a particularly high rate of termination by summary judgment in civil rights and employment discrimination cases False Summary judgment motions by defendants are more common in such cases, are more likely to be granted, and more likely to terminate the litigation.") (quoting Memorandum from Joe Cecil \& George Cort, Fed. Judicial Ctr., to Judge Michael Baylson, 15 tbl. 12 (Aug. 13, 2008), available at http://www.fjc.gov/public/pdf.nsf/lookup/insumjre.pdf/\$file/insumjre. pdf.)).

165. See FED. R. CIV. P. 56 ("The court shall grant summary judgment if the movant shows that there is no genuine dispute as to any material fact and the movant is entitled to judgment as a matter of law."). 
existence of dueling experts means only that there is a factual dispute about the relevant meaning of a word or phrase, and the jury must choose between two views on the issue.

The suggestion to allow expert testimony on language is not a foreign concept in employment discrimination law, but instead is closely related to evidence with which courts are already familiar. Since the 1970 s, social science expert evidence has regularly been relied upon in both disparate treatment and disparate impact cases. ${ }^{166}$ Such evidence is currently categorized as: (1) "social fact" expert testimony, in which research is conducted to answer a specific question posed by a case; (2) "social authority" expert evidence, which is "general social science evidence presented to establish the validity of a factual assumption underlying a legal standard"; and (3) finally, the most recent and most debated, "social framework" expert evidence, in which an expert describes general research results that are "used to construct a frame of reference or background context for deciding factual issues crucial to the resolution of a specific case."167 Social framework evidence is typically employed in cases in which racial or gender stereotypes play a role, and the plaintiff contends that policies in a particular workplace tended to permit or discourage those stereotypes and result in unlawful bias. ${ }^{168}$ As Hart and Secunda point out: "The function of this form of testimony is to supply the triers with information about some aspect of human behavior to aid in interpreting disputed facts. This evidence is often offered to challenge erroneous assumptions that a fact finder is likely to make without the assistance of the expertise."169 Social science evidence thus plays the role of extralegal advisor, providing courts and juries with information that is not otherwise obtainable within the adjudicative process.

The linguistic, sociological, or psychological evidence that would be offered in a case involving the meaning of allegedly discriminatory language would play much the same role. Presenting an amalgam of "social authority" evidence and "social framework" evidence, experts on language could testify to the context-driven nature of language, to the development of a specific word or phrase, to that phrase's use in modern

166. See generally Susan T. Fiske \& Eugene Borgida, Standards for Using Social Psychological Evidence in Employment Discrimination Cases, 83 TEMP. L. REV. 867, 867 (2011); Melissa Hart \& Paul M. Secunda, A Matter of Context: Social Framework Evidence in Employment Discrimination Class Actions, 78 FordhaM L. Rev. 37, 48-49 (2009); Susan T. Fiske \& Eugene Borgida, Providing Expert Knowledge in an Adversarial Context: Social Cognitive Science in Employment Discrimination Cases, 4 ANN. REV. L. \& Soc. SCI. 123, 125 (2008); Jane Goodman \& Robert T. Croyle, Social Framework Testimony in Employment Discrimination Cases, 7 BEHAV. SCI. \& L. 227, 229-31 (1989).

167. Hart \& Secunda, supra note 166 , at $43-44$.

168. See id. at 41 .

169. Id. at 43 . 
culture, and to the impact that the context and identity of the speakers and listeners have on those words. This expert testimony, in turn, could be used by the court and fact finders as background for assessing whether the language was evidence of, or tinged in any way with, bias. Although opined on by the expert, the factual assessment of the meaning of the word or phrase in the specific context in which it was used would still be left to judge or jury. The fact finders would merely have the benefit of background knowledge that they might not otherwise possess. In the face of such evidence, it would be far more difficult for an intolerant or ignorant court to dismiss a phrase as neutral or non-racial. And, hopefully, it would not take seven years and an amicus brief from some of the nation's leading civil rights activists to convince a court about the realities of language in modern culture. ${ }^{170}$

While there has been some significant critique of social framework evidence in stereotyping cases, the defenses of this expert evidence are as strong-if not stronger-in the area of language. Critics of social framework evidence largely take issue with it on two fronts: (1) admissibility, given the lack of unanimity in the field, and (2) the extrapolation of laboratory results to conclusions about an actual workplace. ${ }^{171}$

First, with regard to admissibility based on lack of consensus, defenders of social framework evidence point out that "[t]he Federal Rules of Evidence do not require unanimity in a field to permit introduction of expert testimony in litigation." 172 Dueling experts can present opposing views to a judge or jury without running afoul of the Rules.

Second, with regard to the difficulty translating from laboratory to the workplace, defenders of social framework evidence note that this concern goes to the weight of the evidence, not to its admissibility. ${ }^{173}$ And, in the context of language interpretation, experts may testify about laboratory experiments, but, more often than not, they will be describing research done outside of a lab since they are primarily interested in the actual operation of language in real-life settings. As a result, this concern should be far less

170. While the plaintiff in Ash v. Tyson did attempt to introduce testimony on his perception of the word "boy" and the meaning it carries in the American South when spoken by a white man and directed at an African American man, the Eleventh Circuit dismissed this testimony as his subjective perception of the word, having little to do with the intent of the speaker. Although an absurd result on its own, it would be far more difficult for a court to reach such a conclusion if the testimony came from an expert in linguistics rather than the plaintiff himself. See Footnote 102 which is in the Ash section and is related. The point here is different - that an expert's opinion of the meaning of a word likely carries more weight than that of a party.

171. Hart \& Secunda, supra note 166, at 51-52.

172. Id. at 51 (citing Daubert v. Merrell Dow Pharm., Inc., 509 U.S. 579, 597 (1993)).

173. Id. at 52 . 
relevant when considering linguistic anthropology and psychology evidence on the meaning of language.

Finally, the speaker's own knowledge of the meaning of his words must be addressed when employing expert testimony. If experts are required to act as translators for judge and jury, some may question whether it is unjust to punish ordinary speakers for lacking esoteric knowledge about language that only these experts possess. But that question presumes a lack of knowledge on the part of the judge, jury, and the speaker himself. That is not necessarily the case. In fact, experts can provide a window into the mind of the speaker. An expert can explain the dominant meaning of words when certain contextual factors are present. Thus, much like social framework testimony that describes stereotypes at play in a given workplace, linguistic testimony can elucidate biases suggested by language choice. ${ }^{174}$

\section{Burlington as a Case Study for the Potential Role of Expert Evidence}

The benefit of expert evidence on language is evident when considering the role it could have played in the Burlington case. There is no shortage of evidence on the development of the term "nigger" in our society, and this research draws on legal history, psychology, and linguistic anthropology. For example, Randall Kennedy's book delves into the history of the term both in American society and in the law in particular. ${ }^{175}$ Kennedy focuses on the ways in which the word has appeared in legal battles, but also discusses the various meanings and uses of the word in modern culture that largely depend on the context in which it was used and the race of its user. ${ }^{176}$ In fact, Kennedy himself counsels against automatic identification of all users as racists, particularly in the context of employment discrimination cases.

174. In addition, expert testimony may be useful even when the speaker is not alleged to know the meaning of his words. Such a scenario, however, raises questions about liability and intentionality, which are beyond the scope of this Article. The proper role of implicit bias is discussed infra note 190.

175. KENNEDY, supra note 5. See also Randall Kennedy, "Nigger!" As a Problem in the Law, 2001 U. ILL. L. REV. 935 (2001).

176. See KENNEDY, supra note 5 at 36-37 (quoting Professor Clarence Major) (noting that when the word is "used by black people among themselves, [it] is a racial term with undertones of warmth and good will-reflecting ... a tragicomic sensibility that is aware of black history" and adds that although ' $[t]$ raditionally an insult, nigger can also be a compliment, as in 'He played like a nigger.' Historically a signal of hostility, it can also be a salutation announcing affection, as in 'This is my main nigger.' A term of belittlement, nigger can also be a term of respect, as in 'James Brown is a straight-up nigger.' A word that can bring forth bitter terms in certain circumstances, nigger can prompt joyful laughter in others.") 
Perhaps in the context of antidiscrimination law at the workplace ... it is better to err on the side of overenforcement rather than underenforcement. Still, even if that is so, it is important to remember that the N-word is not self-defining. Its actual meaning in any given instance always depends on surrounding circumstances. Deriving an understanding of nigger thus always requires interpretation. ${ }^{177}$

While Kennedy has researched the term from a legal and historical perspective, experts in other disciplines have considered its varied meanings as well. For example, in 2007, Carol Motley and Kellina CraigHenderson published the results of their study on the meaning of the term and reactions to it among blacks of various ethnic origins. ${ }^{178}$ The study considered the following questions: (1) whether the use of and reactions to the term differ as a function of the in-group or out-group status of the sender and receiver; (2) what the term means to African Americans and blacks from the Caribbean and Africa; and (3) whether African Americans and blacks from the Caribbean and Africa express different emotional reactions to the term and whether their reactions differ in intensity. ${ }^{179}$ Their research, based on in-depth interviews, concluded that:

The impact of the context on reactions to nigger were apparent not only in respondents' reported usage of the term but also in the way in which their reactions varied as a function of the in-group or out-group status of the sender and receiver. The meanings were contextually based, and the interpretations reflected social-psychological factors. ${ }^{180}$

Similarly, Milo Dodson of the University of Illinois at UrbanaChampaign has studied reactions of African American college students to the term "nigger." 181 Dodson considered, among other things, whether the

177. Id. at 75-76. Kennedy ultimately argues against always condoning African Americans' use of the word while insisting that it is never appropriate for whites to do so. See id. at 92-104. Essentially, he argues against absolutes, a position not entirely different from my own. Rather than claiming that the word is acceptable in the mouths of some but not others, I argue for a more nuanced consideration of language in general that includes, although not exclusively, a review of the racial (and other) identities of those who use and hear the word when deciding whether it was intended or had the effect of injecting unlawful bias into a workplace.

178. See Carol M. Motley \& Kellina M. Craig-Henderson, Epithet or Endearment? Examining Reactions Among Those of the African Diaspora to an Ethnic Epithet, 37 J. OF BLACK STUD. 944 (2007).

179. See id. at 949 .

180. Id. at 954 . This research, of course, draws on prior psychosocial research on intergroup relations and the impact of the "out group" and "in group" distinctions in people's interactions. For example, Henri Tajifel and John Turner argue that "in the relevant intergroup situations, individuals will not act as individuals, on the basis of their individual characteristics or interpersonal relationships, but as members of their groups standing in certain defined relationships to members of other groups." Henri Tajfel \& John C. Turner, The Social Identity Theory of Intergroup Behavior, in PSYCHOLOGY OF INTERGROUP RELATIONS 7-24 (Stephen Worchel \& William G. Austin eds., 1986).

181. See id. 
race of the speaker impacted the subject's acceptance or rejection of the use of the term. ${ }^{182}$ This study again was not conducted in a laboratory, but instead involved in-depth interviews of students who discussed their understanding of the developing meaning of the word and the impact of context on that meaning. ${ }^{183}$ Dodson's study concluded that "it is not necessarily the specific form of the n-word that determines appropriateness, but rather the race of the speaker." 184

The work of these scholars are just a smattering of examples of the type of expert evidence that could be presented in a case like Burlington, in which the meaning of the term is highly relevant to the question of alleged discrimination by an employer who terminated an employee for using the word. While not conclusive, an employer could make a case, based on this evidence, that the word has fundamentally different meanings depending on the context in which it is used and depending on the race of the user. As a result, the employer could argue that it is permissible under Title VII to consider an employee's race in determining whether disciplinary measures are appropriate because the employee's racial identity informs the meaning of his or her words and their severity. By the same token, the employer could argue that it is impossible to find similarly situated comparators ${ }^{185}$ who are African American because, by the very nature of their racial identity, such comparators are not similarly situated since their use of the word is a fundamentally different act incomparable to the use of the word by a white co-worker. At the same time, a plaintiff could attempt to invalidate the employer's expert evidence or rely on his own experts to suggest that while word meaning is fluid, the race of the speaker is not the only determinant of a word's meaning and thus, it is an inappropriate criteria on which to judge his actions. At a minimum, the question of the meaning of language would not be ignored, nor would the court be forced to look only to other courts' definitions of a constantly changing term.

\footnotetext{
182. See id.

183. See id.

184. Id.

185. Pointing to "similarly situated comparators" is one means of satisfying the plaintiff's burden to prove that the employer's proffered legitimate nondiscriminatory reason is pretextual. See, e.g. Simpson v. Kay Jewelers, Div. of Sterling, Inc., 142 F.3d 639, 645 (3d Cir. 1998) (explaining that to establish a pretext for discrimination, a plaintiff may "show that the [employer] has previously discriminated against [him], that the [employer] has discriminated against other persons within [his] protected class or within another protected class, or that the [employer] has treated more favorably similarly situated persons not within the protected class").
} 


\section{B. Potential Weaknesses and Questions Raised by This Solution}

This Article suggests that incorporation of expert evidence on the meanings and development of language, along with guidance from the Supreme Court counseling interpretation of language in light of a flexible reading of antidiscrimination law, is ultimately the most effective approach to resolving the problem of misinterpretation of discriminatory language by courts. Nonetheless, there are fundamental questions and structural issues to this strategy that must be addressed.

First, as a threshold matter, critics may question whether fundamental change is truly necessary or whether this problem can instead be dealt with on a case-by-case basis. For example, pointing to Ash v. Tyson, critics may justifiably point out that the Eleventh Circuit eventually recognized the error of its ways and meaningfully considered the definition of "boy" in the context in which it arose in that case. The appeals process (and motions for reconsideration) works on some level to check the ignorance or hastiness of lower courts that fail to consider contextual realities in interpreting discriminatory language. But such a case-by-case approach is not an adequate solution. It should not have taken seven years, a Supreme Court opinion, two jury trials, four appellate opinions, and an amicus brief by many of the country's leading civil rights leaders for the plaintiff in Ash to obtain the favorable judgment to which he was plainly entitled. That was too cumbersome, lengthy, and expensive a process. Had the Supreme Court given more robust guidance in its opinion on the case, and had the plaintiff been encouraged to present expert testimony, it would have been much more difficult for the Eleventh Circuit to ignore the realities of linguistic meaning. Although the court, in its first review of the second trial, managed to disregard the testimony by the plaintiffs on their experience of the term, testimony by an expert based on thoughtful and considered study of language is far more difficult to overlook. ${ }^{186}$

Second, there are fair questions regarding consistency and foreseeability when considering the solution this Article proposes. ${ }^{187}$ If courts cannot look to other cases for definitions of discriminatory words or phrases and must instead consider expert testimony in an effort to better understand historical and cultural context, consistency among opinions will undoubtedly suffer. Litigants will not be able to predict with any certainty the outcome of a case in which the meaning of an allegedly discriminatory

186. We also cannot sit back and assume that once a court properly deals with a specific term or phrase, the law is settled on that issue. Language is constantly changing and the solution to the problem of language interpretation must account for linguistic developments and the changing nature of majorityminority interactions in this country.

187. See Sperino, supra note 144, at 123-24 (discussing similar critiques of her proposal to rethink the rubrics employed in antidiscrimination law). 
term is relevant. While consistency and predictability are valuable goals in a judicial system, inconsistency may, in fact, be desirable in cases involving language. As discussed above, language is inherently fluid, constantly changing, and largely dependent on contextual factors that are anything but static. Once courts acknowledge that reality, consistency among cases involving language would be utterly dishonest. Rather than aiming for certainty, courts should aspire to realism, fairness, and comportment with the purposes of antidiscrimination law.

Third, the question of efficiency must also be raised when considering the allowance and even encouragement of expert testimony in such cases. ${ }^{188}$ Had the plaintiff in Ash introduced expert testimony on the term "boy," it certainly would have added significant expense to the litigation, much more so than his own testimony on the subject. But it likely would have been less expensive than four trips to the Circuit Court, a trip to the Supreme Court, and two jury trials. Although not every case involves such a lengthy process to justice, the added expense of expert testimony in this area is justified but not required. Plaintiffs (and, in cases like Burlington, defendants) will have to weigh the relative cost and benefit of expert testimony depending on the language at issue in the case and the possibility for confusion or dispute over its meaning. This is by no means a reason to preclude such evidence.

Finally, and perhaps most importantly, both the identification of this problem of language interpretation and the solution this Article proposes raise fundamental questions about the proper role of animus in discrimination cases. If the evidence successfully demonstrates a word's biased connotations in the context in which it was used, must the plaintiff also prove that the speaker knew and understood those biased connotations when he used the word? Or is mere use of contextually racist language sufficient? ${ }^{189}$ Should courts be employing a "knew or should have known" type test once the evidence establishes that a word carried a certain meaning, or is actual knowledge required to impute bias? These questions can be situated in a far larger debate in employment discrimination law about the role of unconscious or implicit bias, negligent discrimination, and the appropriate reach of Title VII and other antidiscrimination statutes. ${ }^{190}$

188. The question of efficiency is not raised by the second part of the solution, which involves more robust guidance from the Supreme Court since that will cost a great deal in one case only but save enormous amounts of money in future cases.

189. See supra note 103 (discussing the role of animus in courts' interpretation of discriminatory language).

190. See generally Linda Hamilton Krieger, The Content of Our Categories: A Cognitive Bias Approach to Discrimination and Equal Employment Opportunity, 47 STAN. L. REV. 1161 (1995) (arguing that bias may be both unintentional and unconscious); Gregory Mitchell \& Philip E. Tetlock, Antidiscrimination Law and the Perils of Mindreading, 67 OHIO ST. L.J. 1023 (2006) (arguing against 
Those questions are beyond the scope of this Article. Suffice it to say that up to now, cases involving discriminatory language, even when mistreating that language and looking for a static definition, have not typically considered the intent of the speaker and instead looked to an "objective" definition of a word or phrase in deciding whether the use was biased or not. ${ }^{191}$ An open question remains as to whether the perception of the listener, so long as it is justified and reasonable, is more important than the conscious intent of the speaker.

\section{CONCLUSION}

The disconnect between cultural realities and courts' interpretations of discriminatory language can create bizarre and ironic results. Although a more meaningful and context-driven consideration of discriminatory language by courts may alleviate this problem, this change is unlikely to come easily. The notion that there is some "objective" truth when it comes to language is reassuring, while the reality of language's fluidity can be disconcerting. This Article's suggestion to look to extralegal expert testimony and refrain from relying on past opinions to determine the biased nature of language may inspire resistance from an institution that thrives on

automatic use of implicit prejudice research in employment discrimination law); Amy L. Wax, Discrimination as Accident, 74 IND. L.J. 1129 (1999) (questioning whether antidiscrimination law should cover unconscious bias); Michael Selmi, Discrimination as Accident: Old Whine, New Bottle, 74 IND. L. J. 1233 (1999) (discussing the importance of, and potential remedies for, unconscious discrimination); Sheila Foster, Causation in Antidiscrimination Law: Beyond Intent versus Impact, 41 HOUSTON L. REV. 1469 (2005) (discussing how cognitive biases interfere with both the intentional discrimination and disparate impact frameworks). See also Hart \& Secunda, supra note 166, at 67-69 (arguing that the debate over social framework evidence is really a debate about the role of implicit bias in discrimination cases).

191. See Saint Francis Coll. v. Al-Khazraji, 481 U.S. 604, 610-11(1987) (citing nineteenth century dictionaries to define "race" in 42 U.S.C. $\S 1981$ ). It should be noted that both Randall Kennedy in his book and Paul Carrington in an article he wrote in response to it, consider the intent of the speaker to be distinctly important in assessing the appropriateness of the use of discriminatory language. See KENNEDY, supra note 5 at 29-30, 99-100; Paul D. Carrington, Incorrect Speech, Incorrect Hearing: A Problem of Postmodern Legal Education, 53 J. LEGAL EDUC. 404, 412 (2003). Carrington, who was criticized by a student after he used the word "slut" in class in order to describe the facts of a defamation suit, notes that "Kennedy's point that the apparent purpose of an utterance informs its meaning is worthy of the attention of all those who have imbibed from literary theorists the idea that meaning is derived from audience response, and who thus justify their insistence on politically correct speech. Even the $\mathrm{N}$ word is capable of benign use. And lawyers who are quick to take offense at inappropriate diction, without respect for the manifest purpose of a writer or speaker, perform professional labors of all kinds under a grave handicap." Paul D. Carrington, Incorrect Speech, Incorrect Hearing: A Problem of Postmodern Legal Education, 53 J. LEGAL EdUC. 404, 412 (2003). Importantly, however, this article contends that the meaning of words is derived both from the intent of the speaker and from the listener's perception, both of which are informed by the larger context in which the utterance occurs. Intention of the speaker may or may not be relevant in discriminatory language cases. 
precedent, tradition, and the stability that comes from those values. But this is an important transition nonetheless.

This Article has considered the problems of misinterpretation of discriminatory language and proposed some initial solutions. It is an oftrepeated axiom that law should reflect reality. This is certainly true when it comes to the interpretation of language, and it is time for courts to endorse realistic and meaningful considerations of context in their evaluations of discriminatory language. 
